\title{
Temporal variation of ecosystem carbon pools along altitudinal gradient and slope: the case of Chilimo dry afromontane natural forest, Central Highlands of Ethiopia
}

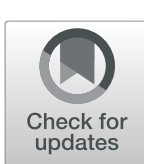

Mehari A. Tesfaye ${ }^{1 *}$, Oliver Gardi ${ }^{2}$, Tesfaye Bekele ${ }^{1}$ and Jürgen Blaser ${ }^{2}$

\begin{abstract}
Quantifying the amount of carbon pools in forest ecosystems enables to understand about various carbon pools in the forest ecosystem. Therefore, this study was conducted in the Chilimo dry afromontane forest to estimate the amount of carbon stored. The natural forest was stratified into three forest patches based on species composition, diversity, and structure. A total of 50 permanent sample plots of $20 \mathrm{~m} \times 20 \mathrm{~m}\left(400 \mathrm{~m}^{2}\right)$ each were established, laid out on transects of altitudinal gradients with a distance of $100 \mathrm{~m}$ between plots. The plots were measured twice in 2012 and 2017. Tree, deadwood, mineral soil, forest floor, and stump data were collected in the main plots, while shrubs, saplings, herbaceous plants, and seedling data were sampled inside subplots. Soil organic carbon (SOC \%) was analyzed following Walkely, while Black's procedure and bulk density were estimated following the procedure of Blake (Methods of soil analysis, 1965). Aboveground biomass was calculated using the equation of Chave et al. (Glob Chang Biol_20:3177-3190, 2014). Data analysis was made using RStudio software. To analyze equality of means, we used ANOVA for multiple comparisons among elevation classes at $a=0.05$. The aboveground carbon of the natural forest ranged from $148.30 \pm 115.02$ for high altitude to $100.14 \pm 39.93$ for middle altitude, was highest at $151.35 \pm 108.98 \mathrm{tC} \mathrm{ha}^{-1}$ for gentle slope, and was lowest at $88.01 \pm 49.72 \mathrm{tC} \mathrm{ha}^{-1}$ for middle slope. The mean stump carbon density $2.33 \pm 1.64 \mathrm{tC} \mathrm{ha}^{-1}$ was the highest for the middle slope, and $1.68 \pm 1.21 \mathrm{t} \mathrm{C} \mathrm{ha}{ }^{-1}$ was the lowest for the steep slope range. The highest $1.44 \pm 2.21 \mathrm{tC} \mathrm{ha}^{-1}$ deadwood carbon density was found under the middle slope range, and the lowest $0.21 \pm 0.20 \mathrm{tC} \mathrm{ha}^{-1}$ was found under the lowest slope range. The SOCD up to $1 \mathrm{~m}$ depth was highest at $295.96 \pm 80.45 \mathrm{tC} \mathrm{ha}^{-1}$ under the middle altitudinal gradient; however, it was lowest at $206.40 \pm 65.59 \mathrm{tC} \mathrm{ha}^{-1}$ under the lower altitudinal gradient. The mean ecosystem carbon stock density of the sampled plots in natural forests ranged from 221.89 to $819.44 \mathrm{tCha}^{-1}$. There was a temporal variation in carbon pools along environmental and social factors. The highest carbon pool was contributed by SOC. We recommend forest carbon-related awareness creation for local people, and promotion of the local knowledge can be regarded as a possible option for sustainable forest management.
\end{abstract}

Keywords: Carbon stock density, Dry afromontane natural forest, Deadwood, Humus, Herbaceous, Mineral soil and stump carbon

\footnotetext{
* Correspondence: meharialebachew25@gmail.com

'Ethiopian Environment and Forest Research Institute (EEFRI), Box 24536

code 1000, Gurd Shola, Addis Ababa, Ethiopia

Full list of author information is available at the end of the article
}

(c) The Author(s). 2019 Open Access This article is distributed under the terms of the Creative Commons Attribution 4.0 International License (http://creativecommons.org/licenses/by/4.0/), which permits unrestricted use, distribution, and reproduction in any medium, provided you give appropriate credit to the original author(s) and the source, provide a link to the Creative Commons license, and indicate if changes were made. The Creative Commons Public Domain Dedication waiver (http://creativecommons.org/publicdomain/zero/1.0/) applies to the data made available in this article, unless otherwise stated. 


\section{Background}

Forest provides goods, such as wood and non-wood forest products (NWFP), and ecosystem services, such as biodiversity protection, fresh water supply, soil protection, and climate regulation, which are important for the well-being of the people at local, national, and global levels. Forests mitigate atmospheric $\mathrm{CO}_{2}$ as sinks in its carbon pools (C sequestration). IPCC (2013) reported that the global forest cover is 4 billion hectares and represents over $50 \%$ of global greenhouse gas mitigation potential (IPCC 2007). Tropical, humid, and dry forests spread over 2.1 billion hectare area worldwide, store $180 \mathrm{Gt} \mathrm{C}$ stock in biomass, and have a turnover of 915 Gt of carbon each year (Millennium Ecosystem Assessments 2005; Baccini et al. 2008; FRA 2015). Tropical dry forests cover over $840,000,000$ ha, constitute a net terrestrial primary production of $40 \%$ of all tropical forests, and store $60 \%$ carbon which contain half of the world's tree species (Miles et al. 2006; Chidumayo et al. 2011).

The major carbon pools in forest ecosystems are aboveground and belowground biomass, deadwood, litter, and soil organic carbon (FAO 2005; IPCC 2003, 2006). Aboveground biomass (AGB) includes all living biomass above the soil, while belowground biomass (BGB) includes all biomass of live roots excluding fine roots ( $<2 \mathrm{~mm}$ diameter) (Brown 1997; IPCC 2003). Deadwood organic carbon includes coarse and fine deadwood found in the form of logged, standing and lying deadwood (Takahashi et al. 2010; Kassa 2015). Litter carbon is found in the form of fallen leaves, twigs, and undecomposed litter (Lemma et al. 2007). The soil is the largest carbon reservoir of the terrestrial carbon cycle storing 1500-1550 Gt of organic carbon. About three times more carbon is contained in soils than in the world's vegetation $560 \mathrm{Gt}$, and soils hold more than twice the amount of carbon, i.e., present in the atmosphere 720 Gt (Post et al. 2001; Lal 2004). Forest soil is part of any forest ecosystem and stores about $40 \%$ of the total SOC of the global soils (Baker 2007; Rooney 2013).

The carbon pools in forest ecosystems are affected by altitude, slope, and land-use types (Diawei et al. 2006). Bhat et al. (2013) indicated that land use, land-use changes, soil erosion, and deforestation are the most important factors affecting the carbon stock density in the forest ecosystem. According to Feyissa et al. (2013), forest carbon is affected by altitude and slope. Altitude has a significant effect on temperature and precipitation. This strongly affects the species composition, the diversity, the quantity, and the turnover of forest ecosystem (Sheikh and Bussmann 2009). Hamere et al. (2015) assessed the impact of slope in above and belowground biomass, soil organic carbon, and total ecosystem carbon, in which east slope aspect showed the highest, whereas south slope aspect showed the lowest total carbon stock. In the tropics, land use affects the global carbon cycle by increasing the rate of carbon emissions (Silver et al. 2000). Conversion of forest land use type into agricultural land use types reduced SOC stock density by $20-50 \%$ (Solomon et al. 2002; Lemenih and Itanna 2004; Lal 2005).

Ethiopia is endowed with various landscape types. Accordingly, the vegetation types are diverse and vary from tropical humid forests and cloud forests located in the southwest to desert scrubs in the east and northeast (Bongers and Tenngkeit 2010). The natural high forests of Ethiopia are mainly found in the highlands where annual rainfall distribution and amount is better, with a maximum mean annual rainfall of more than $1000 \mathrm{~mm}$ year $^{-1}$. Around $90 \%$ of the total population live in the highlands, which covers $44 \%$ of the country's land mass. Moreover, the great majority (93\%) of the cultivated land and the country's livestock population $(75 \%)$ is found in the highlands.

The national carbon stock of Ethiopia was estimated to be 153 teragram (Tg) of C by Houghton (1998), 867 Tg of C by Gibbs et al. (2007), and 2.5 Gt of C by Sisay (2010). The natural high forest carbon stock ranges from 101 to $200 \mathrm{Mg} \mathrm{Cha}^{-1}$ (Brown 1997; Moges et al. 2010; Temam 2010; Tsegaye 2010). The discrepancy between these values sees to be the different methods and tools used by the authors and the variability in soil, topography, and forest types. Thus, localized carbon stock assessment studies should have been done (IBC 2005; Moges et al. 2010). However, relatively little is currently known about the intersite and temporal variability of forest biomass when compared to a large amount of information available in other continents (Chave et al. 2001; Girma et al. 2014; Hassen 2015). Periodic forest inventories and continuous monitoring and assessment works in the country are lacking, even though they are most useful in order to evaluate the magnitude of carbon fluxes between AGB and the atmosphere (Girma et al. 2014). According to Adugna et al. (2013), information on carbon stocks of forest is limited in Ethiopia. Similarly, Meles et al. (2014) also noted that, although the carbon pool varies between vegetation types and soil types, there is a limited number of studies except few works by Hassen (2015), Gebre (2015), Tesfaye (2015), Yahya (2015), and Wodajo (2018).

Chilimo forest is composed of mixed broad-leaved Podocarpus falcatus, Olea europea ssp. cuspidiata, Scolopia theifolia, Rhus glutinosa, Olinia rochetiana, and Allophylus abyssinicus, and coniferous forest species Juniperus procera are the major species in the forest (Bekele 2003; Kelbessa and Soromessa 2004; Kassa et al. 2008). Accordingly, Shumi (2009) investigated 42 species, $27(64 \%)$ of trees and $15(36 \%)$ of shrubs in the forest. Similarly, the inventory result of Tesfaye et al. (2016) 
found a total of 33 different native species (22 tree species and 11 shrub species) in three forest patches (Chilimo, Gallessa, and Gaji). The density also varied from 2533 stems per hectare found in Chilimo to 848 stems per hectare found in Gallessa patch. Like in many parts of Ethiopia, Chilimo forest was previously a closed dense forest before the Italian occupation (1936-1941) (Shumi 2009). However, the Italians had established a camp and introduced seven saw mills inside Chilimo forest for timber extraction. This resulted in intensive exploitation of high value timber native tree species under Chilimo dry afro montane forest since long years ago. Chilimo forest was among the most commercially exploited forests in the country. Its accessibility and proximity to market centers including Addis Ababa, the capital of Ethiopia, contributed to its exploitation (Bekele 2003). Higher timber extraction rates along with overgrazing and agricultural expansion in the forest radically reduced the forest area from 22,000 ha in 1982, 11,000 ha in 1984, 6000 ha in 1991, and 4500 ha in 2016 (Shumi 2009; Teshome 2017). It has also been reported that some plant species are becoming endangered due to deforestation (Soromessa and Kelbessa 2014).

Some years ago, participatory forest management approach was established by non-governmental organization, i.e., Farm Africa (Negassa and Wiersum 2006), where all parts of Chilimo forest was managed by the community. However, Farm Africa had left its engagement, and then, in 2005, the forest was transferred to Oromia Wildlife and Forest Enterprise. Currently, the Chilimo forest is jointly managed by 12 Forest User Groups (FUGs) under the umbrella of Oromia Wildlife and Forest Enterprise (OFWE). In and around the forest, there are more than 4000 households with a total population of about 20,000 people who are living (Tesfaye et al. 2016). The forest was divided into nine forest compartments (patches), and each compartment is managed by each kebele administration. Forest in Chilimo has the highest share for the livelihood of people, i.e., it contributes almost an equal amount to agriculture for livelihoods (Negassa and Wiersum 2006; Kassa et al. 2008).

The Chilimo forest is characterized by different altitudinal gradient, slope range, forest patch, and land-use types, and given that the temporal variation in carbon pools along these factors are not yet known, we therefore hypothesized that there is a temporal variation in carbon pools along environmental variables, forest patch, and land-use types. The main purpose of this study is therefore to determine temporal variation in carbon pools along environmental gradient and slope in Chilimo dry afromontane forest. The specific research questions to be addressed are as follows: (i) Is there a temporal variation in carbon pools along the altitudinal gradient, slope, and forest patch? (ii) Does temporal variation occur in humus and litter carbon pools? (iii) Is there any temporal variation in the SOC stock across land-use categories and soil depth? (iv) Is there any correlation among carbon pools in the natural forest? (v) Do environmental factors and forest patch affect the total ecosystem carbon?

\section{Material and methods Description of the study site}

The Chilimo forest contains a total of 4500 ha. For administrative purposes, the forest has been partitioned into nine compartments (forest patches) as a part of the management scheme of Oromia Forest and Wildlife Enterprise (Fig. 1). This study was conducted in the largest forest patches of the forest which are Chilimo, Galless, and Gaji. The sampled plots are geographically located at $038^{\circ} 08^{\prime} 679^{\prime \prime}$ to $038^{\circ} 10^{\prime} 283^{\prime \prime}$ E latitude and $09^{\circ}$ $04^{\prime} 038^{\prime \prime}$ 'to $09^{\circ} 05^{\prime} 765^{\prime \prime} \mathrm{N}$ longitude, at an altitude of 2470 to $2900 \mathrm{~m}$ above sea level (Fig. 1) in Dendi District, Western Shewa Zone, Oromia Administrative Region, and Central Highlands of Ethiopia. Chilimo forest is one of the few remnant of dry afromontane forests located in the Central Highlands of Ethiopia. This forest is characterized by a small enclave in the western section of a chain of hills and ridges that stretch over $200 \mathrm{~km}$ from north of Addis Ababa westwards up to the Ghedeo highlands in the west, and local river valleys and gorges cut through the chain. Awash river, one of the longest river in the country, originates from this forest and is the home of over 180 species of birds and 21 species of mammals (Woldemariam 1998). Chilimo forest is composed of mixed broad-leaved Podocarpus falcatus, Olea europaea, Scolopia theifolia, Rhus glutinosa, Olinia rochetiana, and Allophylus abyssinicus, and Juniperus procera are the major species in the forest (Bekele 2004; Kelbessa and Soromessa 2004; Kassa et al. 2008). While Shumi (2009) investigated 42 species composed of 27 tree and 15 shrub species in the forest, Tesfaye (2015) reported for Chilimo 33 different native woody species (22 tree species and 11 shrub species) in three forest patches. On their part, Soromessa and Kelbessa (2014) reported 213 different plant species which belong to 83 families, and 18 plant species are recorded as endemic, from which one was endangered and three were evaluated as vulnerable to the Chilimo forest (Kelbessa and Soromessa 2004).

For over a century, Chilimo forest was owned and controlled by the State. Nevertheless, the State control had weakened from 1991 to 1996. This resulted in an increasing conversion of the forest into agricultural land and illegal cutting of trees for timber, construction wood, and fuelwood. Thus to minimize deforestation of the remaining forest, the government classified 58 natural forests as National Forest Priority Areas NFPAS in cluding Chilimo forest was one of them (Shumi 2009). The 

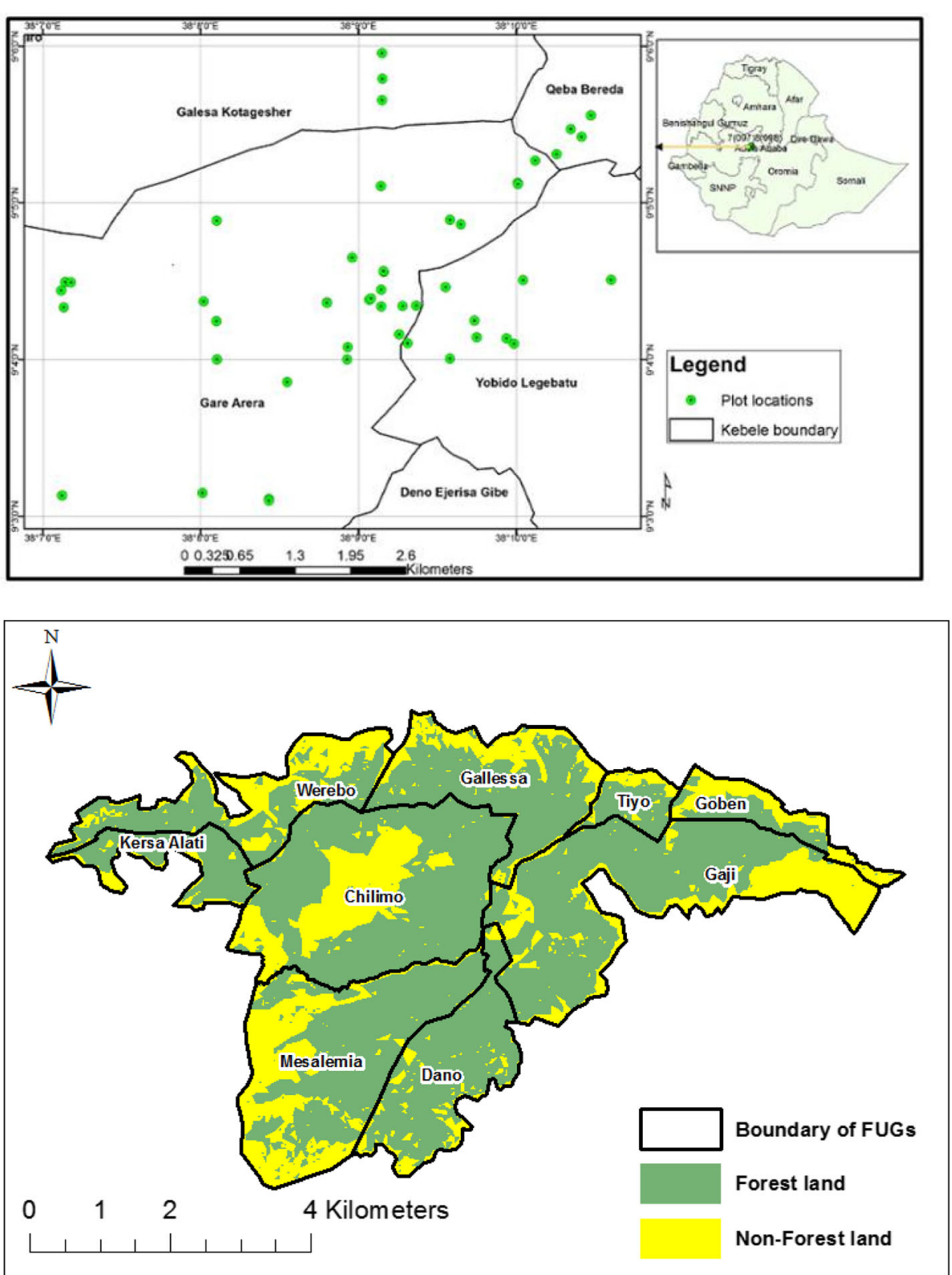

Fig. 1 Sampling plot distribution of the Chilimo dry afromontane forest

mean annual temperature of the area ranges between 15 and $20^{\circ} \mathrm{C}$, and the mean annual precipitation ranges from 1000 to $1264 \mathrm{~mm}$ (Shumi 2009). Following Köppen's classification, the climate of Chilimo forest could be classified as warm temperate climate I (CWB) type (EMA 1988).

\section{Field sampling}

\section{Reconnaissance survey}

Discussions were held with Oromia Wildlife and Forest Enterprise office in Addis Ababa for awareness creation and issuance of authorizations to work in this forest. Subsequently, after the permit, a reconnaissance survey was conducted through a field visit and a physical observation across the forest. Three forest patches were selected for further in-depth study based on their accessibility, species composition, and representativeness. Then an inventory was conducted in Chilimo, Gallessa, and Gaji forest patches. The survey also covered the adjacent land-use types, which include plantation forests, cultivated land, and degraded lands.

\section{Sampling design}

A systematic sampling approach was used to carry out the inventory. A total of $3520 \mathrm{~m} \times 20 \mathrm{~m}\left(400 \mathrm{~m}^{2}\right)$ squared sampled plots (20 plots in Chilimo, 11 plots in 
Gallessa, and 4 plots in Gaji forest patches) were established, based on Neyman's optimal proportional allocation formula in the natural forest (Kangas and Maltamo 2006; Köhl et al. 2006) (Fig. 2). In addition, nine sample plots of $20 \mathrm{~m} \times 20 \mathrm{~m}$ were established in the plantation of Cupressus lusitanica, Eucalyptus saligna, and Pinus patula forests (three in each) along an altitudinal gradient. Additionally, six plots under cultivated land and degraded land (three in each) were laid out for soil sampling. The total number of plots was 50 in natural and plantation forests and cultivated and degraded lands. The center of the first plot was laid out systematically using Silva compass, $150 \mathrm{~m}$ away from the outer edge following north direction to avoid edging effect. To attain a $90^{\circ}$ corner of the main plots, the Pythagoras theorem was applied. Then, four sharpened wooden pegs were stalked in the four corners of the main plot. The plots were laid out along $100 \mathrm{~m}$ ground distance, starting from the highest to the lowest ridges of the mountains using a measuring tape, GPS, and compass. A total of ten transect lines (four in Chilimo, four in Gallessa, and two in Gaji) were made along the center of the natural forest. The distance between two consecutive transect lines was $300 \mathrm{~m}$ and $1 \mathrm{~km}$, respectively, depending on the accessibility of the next transect. A first inventory was conducted in 2012, and remeasurements were conducted within the same established sampling plots and for the same numbered trees in 2017. Soil samples were also taken from adjacent land-use types (cultivated land and degraded land) $1 \mathrm{~km}$ away from the outer edge of the natural forest. The horizontal distance between sampling plots in these land-use types was also $100 \mathrm{~m}$, and transect lines were made from bottom to top parts of the gradient.

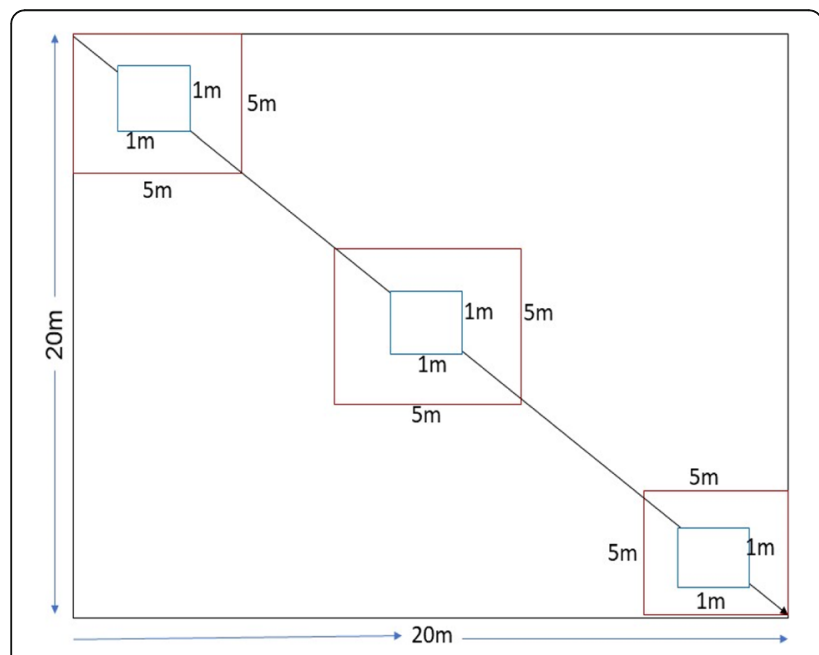

Fig. 2 Design of the sampling plots of the Chilimo dry afromontane forest

\section{Field data collection}

Before the actual measurements started, all trees and shrubs found in the border of each plot were marked, and then, all trees in the main plot were numbered. Individual species were categorized into trees $(\geq 5 \mathrm{~cm}$ diameter at breast height $[\mathrm{DBH}]$ ), shrubs, saplings (height $\geq$ $1.3 \mathrm{~m}$ and DBH $2.5-5 \mathrm{~cm}$ ), and seedlings (height 0.30 $1.3 \mathrm{~m}$ and $\mathrm{DBH} \leq 2.5 \mathrm{~cm}$ ) following Lamprecht's classification (Lamprecht 1989). Tree measurements were conducted in the $20 \mathrm{~m} \times 20 \mathrm{~m}$ main plot, while shrubs and saplings were measured in $3.5 \mathrm{~m} \times 5 \mathrm{~m}$ subplots and seedling measurements were made in $3.1 \mathrm{~m} \times 1 \mathrm{~m}$ subplots. Tree diameter $(\mathrm{cm})$ was measured using a metallic caliper for small- and medium-sized trees, while diameter tape was used for bigger tree measurements. Height was measured to the nearest two digits using Vertex III digital electronics tree height measurement instruments. In cases where trees branched at below the breast height, the diameter was measured separately for each branch and was the square root of diameter squared $(\sqrt{\text { Dbhi2 }+ \text { Dbhii } 2})$. Likewise, the diameter at each stem was measured separately for trees with multiple stems connecting near to the ground. For irregularities and/or buttresses on large trunks, measurements were taken at the nearest lower points. Height and diameter measurements for shrubs and saplings were done using graduated wooden bars and metallic caliper. Counting and average height measurement for seedlings were made using a wooden ruler.

\section{Data analysis}

For the purpose of analysis, environmental factors and forest patches were categorized into three discrete classes: the altitudinal gradient as class 1 (low elevation) $\leq$ $2599 \mathrm{~m}$, class 2 (middle elevation) $2600-2699 \mathrm{~m}$, and class 3 (high elevation) $\geq 2700 \mathrm{~m}$ and slope class as slope 1 (gentle slope) $\leq 25 \%$, slope 2 (middle slope) $26-50 \%$, and slope 3 (steep slope) 51-70\%; data for the different carbon pools both in the natural forest and other land uses were analyzed using RStudio (R-Development Core team, 2017). To analyze the equality of means, we used ANOVA for multiple comparisons among elevation classes at $\alpha=0.05$.

\section{Aboveground biomass}

Aboveground biomass was calculated using the equation of Chave et al. (2014) (Eq. 1)

$$
\mathrm{AGB}=0.0673(\rho H D b h 2)^{\wedge} 0.976
$$

where AGB is the above ground biomass (in $\mathrm{kg}$ ), $\mathrm{Dbh}$ is the diameter at breast height (in $\mathrm{cm}$ ), $H$ is the height (in $\mathrm{m}$ ), and $\rho$ is the basic wood density (in $\mathrm{g} \mathrm{cm}^{-3}$ ). The wood density data information were obtained from the 
Global Wood Density Database (Zanne et al. 2009), ICRAF Wood Density Database (www.worldagroforestry. org), and Wood Technology Research Centre, Addis Ababa (Desalegn et al. 2012). In addition, wood densitity for Allophyllus abyssinicus, Olea europea subspp cuspidiata, Olinia rochetiana, Rhus glutinous, and Scolopia theifolia was used from Tesfaye (2015).

Accumulated aboveground and total carbon density was calculated following Eqs. 2 and 3:

$$
\mathrm{ACD}=\mathrm{AGB} \times 0.47
$$

(IPCC 2006)

$$
\mathrm{BCD}=\mathrm{ACD} \times 0.24
$$

(Gibbs et al. 2007; Ponce-Hernandez 2004)

where $\mathrm{ACD}$ is the aboveground carbon density $\left(\mathrm{tC} \mathrm{ha}^{-1}\right)$ and $\mathrm{BCD}$ is the belowground carbon density $\left(\mathrm{tC} \mathrm{ha}^{-1}\right)$.

The accumulated aboveground and total carbon densities for each tree were calculated separately in each plot, and then, figures for the carbon density of each tree were summed up to give a plot accumulated carbon density and converted to per hectare. The plots were stratified along altitudinal gradient, slope percent, forest patch, and land-use types using $\mathrm{R}$ software (R-Development Core Team 2017).

\section{Herbaceous biomass sampling and analysis}

Sampling at the herbaceous layer was made in the interior of three subplots for the inventory of herbs and grasses in 2017. Harvesting of herbs and grasses was made using sickles, and fresh weight of all samples was recorded in the field using string balance. Then, $500 \mathrm{~g}$ of fresh sample was taken to the laboratory to determine the water content and dry biomass.

The samples were oven dried at $70^{\circ} \mathrm{C}$ for $24 \mathrm{~h}$ and weighed again to obtain the dry matter of the sample, and these data were used for the calculation of Eq. 4:

$$
\begin{aligned}
\mathrm{HbCD}= & \left(W_{\text {sample }}(\text { dry })\right) /\left(W_{\text {sample }}(\text { fresh })\right) \\
& \times W_{\text {field }} / 3 \times 0.47 \times 10000 / 10^{6}
\end{aligned}
$$

where $\mathrm{HbCD}$ is the herbaceous carbon density $\left(\mathrm{tCha}^{-1}\right)$, $W_{\text {sample }}$ (dry) is the sample oven-dried weight, $W_{\text {sample }}$ (fresh) is the sample fresh weight, and $W_{\text {Field }}$ is the total fresh weight of the samples collected.

\section{Coarse wood debris sampling}

Deadwood was sampled in 11, 6, and 1 plots in Chilimo, Gallessa, and Gaji forest patches, respectively. Coarse wood debris (logs and cut stumps) were inventoried within the $20 \mathrm{~m} \times 20 \mathrm{~m}$ plots. All fallen branches and/or twigs of $2 \mathrm{~cm}$ diameter and above were collected and measured in the field using string balance. The weight of big logs was estimated in the field manually. For fallen branches and twigs, subsamples were taken into the laboratory. All fallen branches/twigs of $2 \mathrm{~cm}$ diameter and above were oven dried at $102{ }^{\circ} \mathrm{C}$ for $24 \mathrm{~h}$.

\section{Stump biomass}

Stumps were sampled inside the $20 \mathrm{~m} \times 20 \mathrm{~m}$ plots. Diameter measurements for all the stumps were made in the main plots in their bases and at the top using a metallic caliper and diameter tape, while height measurements were done using a measuring tape. To calculate the stump carbon, first, the volume was calculated using Smalian's formula (Nicholas et al. 2012) (Eq. 5):

$$
V=\pi / 8 L\left(D_{1}^{2}+D_{2}^{2}\right)
$$

where $V$ is the volume $\left(\mathrm{cm}^{3}\right), L$ is the length of the trunk (cm), $D_{1}{ }^{2}$ is the diameter of the narrow end of the trunk $(\mathrm{cm})$, and $D_{2}{ }^{2}$ is the diameter of the large end of the trunk $(\mathrm{cm})$. Once the volume was determined, the mass was calculated as follows (Eq. 6):

$$
m_{\mathrm{i}}=\rho_{\mathrm{i}} \times V_{\mathrm{i}}
$$

where $m_{\mathrm{i}}$ is the mass in kilograms, $\rho_{\mathrm{i}}$ is the density $\left(\mathrm{g} \mathrm{cm}^{-3}\right)$, and $V_{\mathrm{i}}$ is the volume.

\section{Forest floor and litter sampling and analysis}

Litter, intermediate, and humus samples were taken within a $0.25 \mathrm{~m} \times 0.25 \mathrm{~m}\left(0.0625 \mathrm{~m}^{2}\right)$ metallic frame in the center of the main plot where available, while depth of the forest floor was measured using a metallic ruler. The collected materials were taken into the laboratory for analysis for water content and dry weight.

The sampled litter, intermediate, and humus layers were oven dried at $70^{\circ} \mathrm{C}$ for $24 \mathrm{~h}$ in the laboratory and weighed using sensitive balance. Chemical analysis for the humus and intermediate layer was performed using the loss-on-ignition method (Ben-Dar and Banin 1989). Then, soil organic matter was converted into organic carbon following Eq. 7 and Eq. 8:

$$
\begin{aligned}
& \mathrm{SOM}=(w 105-w 400) / w 105 \times 100 \\
& \% \mathrm{C}=\% \mathrm{SOM} \times 0.58
\end{aligned}
$$

where SOC is the soil organic carbon concentration, $\mathrm{SOM}$ is the soil organic matter, $w 105$ is the weight of dry soil sample at $105^{\circ} \mathrm{C}, w 400$ is the weight of ground soil sample at $400^{\circ} \mathrm{C}$, and 0.58 is the carbon concentration in the soil organic matter which has been found to be the most convenient conversion factor from organic matter to carbon content in forest floor (De Vos et al. 2005). Although Pribyl (2010) recommended a value of 0.5 , we retained the 0.58 value in forest floor as it has been commonly used and it allows comparisons with other studies. 
The forest carbon density was calculated using the conversion of humus carbon stock density ( $\mathrm{HuCD}$, in $\mathrm{tC} \mathrm{ha}^{-1}$ ) in the sampled plot following Eq. 9:

$$
\mathrm{HuCD}\left(\mathrm{t} \mathrm{Cha}^{-1}\right)=\frac{\text { HODweight }}{0.0625} \times \frac{c_{\mathrm{p}}}{100} \times 10000 / 10^{\wedge} 6
$$

where $\mathrm{HuCD}$ is the humus carbon density, HOD is the humus oven dry weight, and $C \mathrm{p}$ is the carbon percentage.

\section{Soil organic carbon sampling and analysis}

Mineral soil samples were collected in 18 out of 50 sampled plots in natural forest, 9 in plantations, 3 in cultivated lands, and 3 in degraded lands. Sampling was made layer by layer with 1 -m-long $\times 0.60$-m-wide dug pit at the center of the main plot. Five hundred grams each of four mineral soil layers $(0-10,10-30,30-50$, and 50-100) was sampled and handled with plastic bags. Separate samples were taken at four soil depths for bulk density with a 5-cm-high cylinder that was introduced vertically in the corresponding depth. Resamplings were made in both cases by digging new sample pits $10 \mathrm{~cm}$ away from the older pit following an appropriate direction. A total of 264 (132 mineral soil +132 cores) were collected and transported into the laboratory for organic $\mathrm{C} \%$ and bulk density analyses.

Mineral soil sampled was air dried and passed through a $2-\mathrm{mm}$ sieve to obtain the fine fraction for chemical analysis. The coarse fragments $(2 \mathrm{~mm})$ were removed from the sample, and their percentage of stoniness and
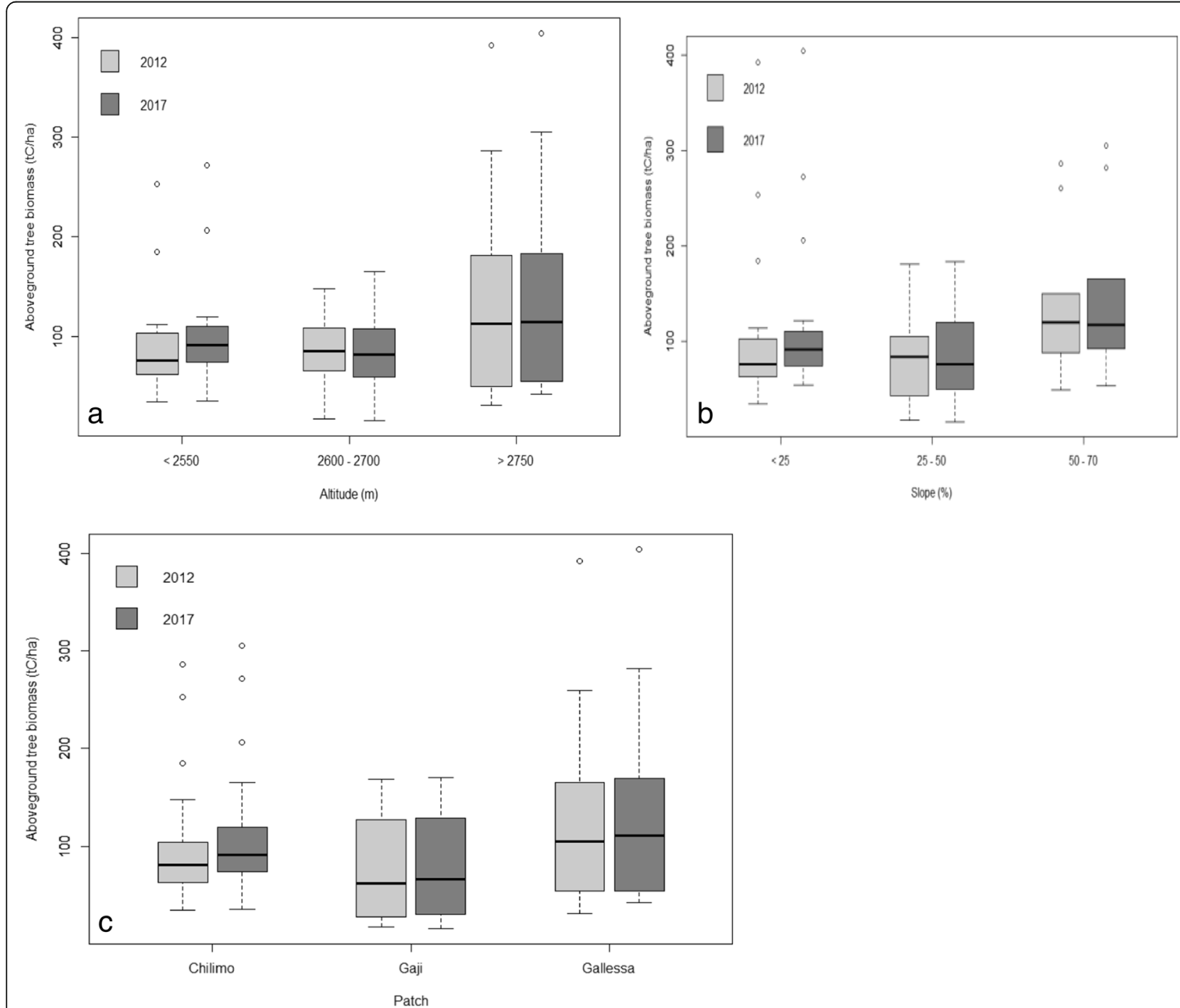

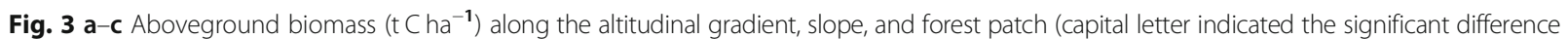
among the altitudinal gradient and slope percent) 
or rockiness was calculated by comparing their mass with the total weight of the oven dried samples at $67^{\circ} \mathrm{C}$ for $24 \mathrm{~h}$ (Eq.10):

$$
\text { CFW\% }=\frac{\text { weight coarse fraction }}{\text { weight of total soil }} \times 100
$$

where CFW is the percentage of coarse fragments by weight (Page-Dumroese et al. 1995). Then, the total organic carbon $(\mathrm{C} \%)$ was analyzed following WalkleyBlack's method described by the Anderson and Ingram (1996) procedure. Bulk density was estimated following the procedure of Blake (1965). The oven-dried soil was weighed and divided by the volume of the metallic cylinder.

The SOC stock density in mineral soil was calculated based on fixed depth method using carbon concentration, thickness of each layer, soil bulk density, and coarse fragmented matter at each depth, according to Eq. 10 (Ruiz-Peinado et al. 2013) (Eq. 11):

$$
\text { SOC stock }=\mathrm{SOC} \text { con.BD. } L(1-\mathrm{CFM}) \times 10
$$

where SOC stock is the soil organic carbon per unit area $\left(\mathrm{t} \mathrm{Cha}{ }^{-1}\right)$, SOC con. is the carbon concentration in the soil layer $\left(\mathrm{kgCt}^{-1}\right.$ soil), BD is the bulk density ( $\mathrm{t}$ soil $\mathrm{m}^{-3}$ ), $L$ is the depth of the sample layer (m), CFM is the percent mass coarse fragmented matter $>2 \mathrm{~mm}$, and the multiplying factor 10 is required to express the result in correct units.

\section{Total forest ecosystem carbon estimation}

The total carbon stock (carbon density) was calculated by summing up all the seven carbon stocks of each

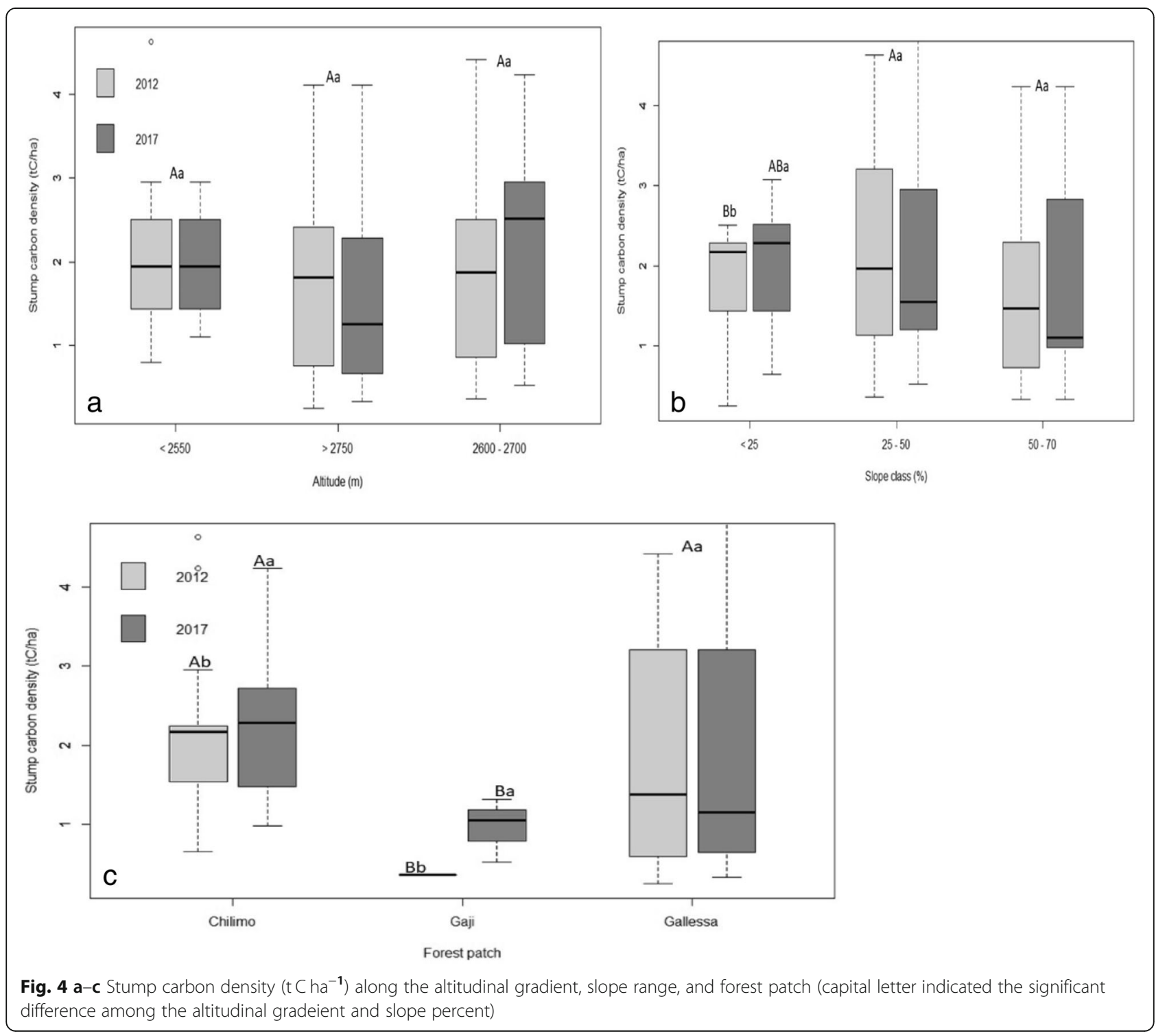


carbon pools of the forest ecosystem following Pearson et al. (2005), then converted into tonnes of $\mathrm{CO}_{2}$ equivalent by multiplying it by 3.67 as developed by Pearson et al. (2007). Carbon stock density of the study area was calculated using (Eq. 12):

$$
\begin{aligned}
\mathrm{TECD}= & \mathrm{ACD}+\mathrm{BCD}+\mathrm{DWCD}+\mathrm{StCD} \\
& +\mathrm{HbCD}+\mathrm{LCD}+\mathrm{HuCD}+\mathrm{SOCD}
\end{aligned}
$$

where TECD is the total ecosystem carbon density ( $\mathrm{C}$ $\left.\mathrm{ha}^{-1}\right), \mathrm{ACD}$ is the aboveground carbon density $\left(\mathrm{tC} \mathrm{ha}^{-1}\right)$, $\mathrm{BCD}$ is the belowground carbon density $\left(\mathrm{tC} \mathrm{ha}^{-1}\right)$, DWCD is the deadwood carbon density $\left(\mathrm{tC} \mathrm{ha}^{-1}\right)$, StCD is the stump carbon density $\left(\mathrm{tC} \mathrm{ha}{ }^{-1}\right), \mathrm{LCD}$ is the litter carbon density $\left(\mathrm{tCha}^{-1}\right), \mathrm{HuCD}$ is the humus carbon density $\left(\mathrm{t} \mathrm{Cha}^{-1}\right), \mathrm{HbCD}$ is the herbaceous carbon density $\left(\mathrm{t} \mathrm{Cha} \mathrm{C}^{-1}\right)$, and SOCD is the soil organic carbon density $\left(\mathrm{t} \mathrm{Cha}^{-1}\right)$.

\section{Correlation and regression analyses}

A multiple regression correlation analysis was performed using R software (R-Development Core Team 2017). Then, a multiple regression correlation matrix graph was developed. Highly correlated carbon pools were selected and further evaluated. A linear correlation analysis graph and a linear equation model were developed, evaluated, and fitted. The best linear models were selected based on the MRES (mean residual for evaluating bias) and the RMSE (root mean square error for evaluating precision).

\section{Results}

Aboveground biomass and belowground carbon biomass The aboveground and belowground biomass varied significantly among the altitudinal gradient and slope percent $P \leq 0.05$. However, there was non-significant among time and forest patch (Table 2; Fig. 3a-c). The aboveground and belowground biomass was the highest for

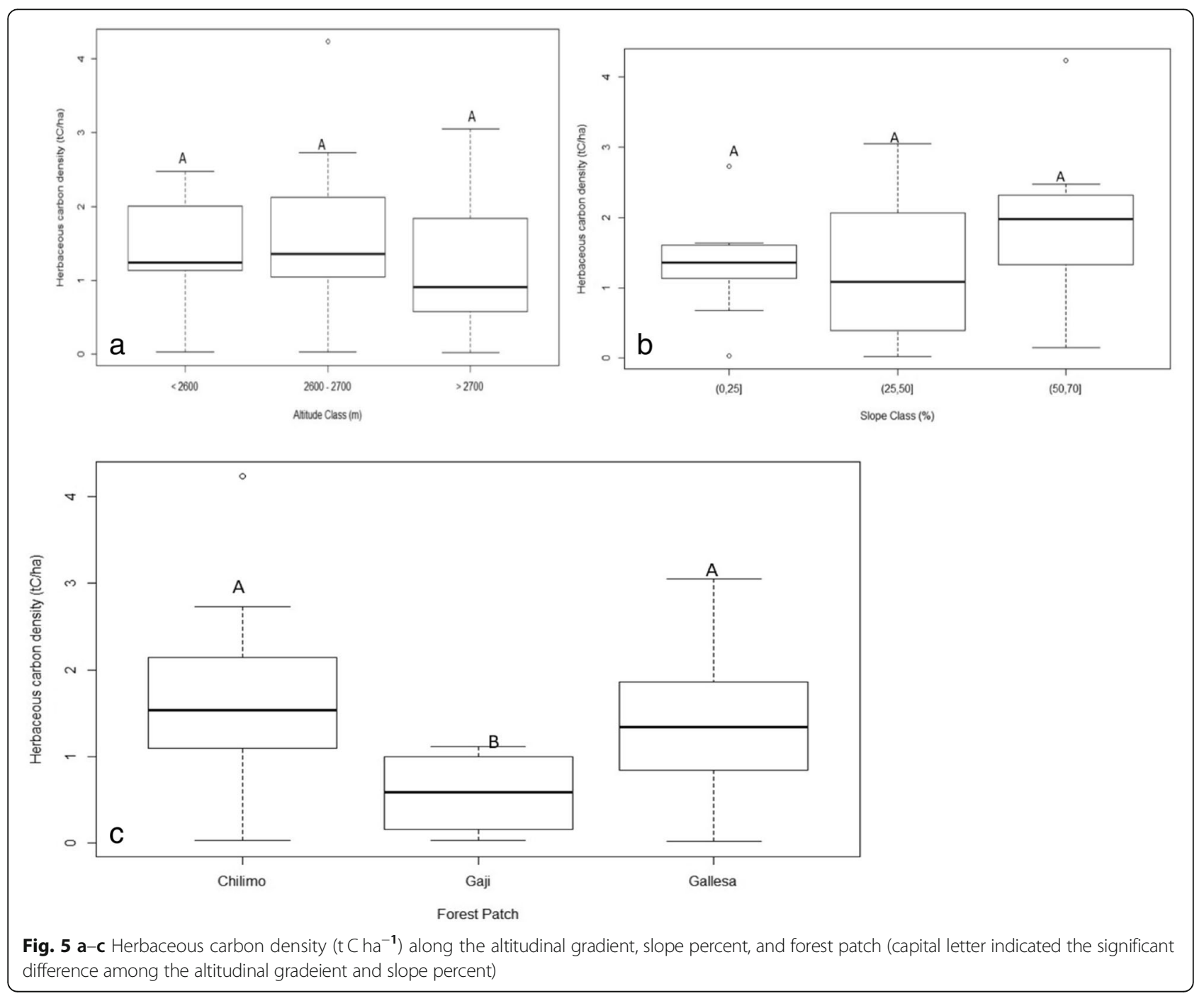




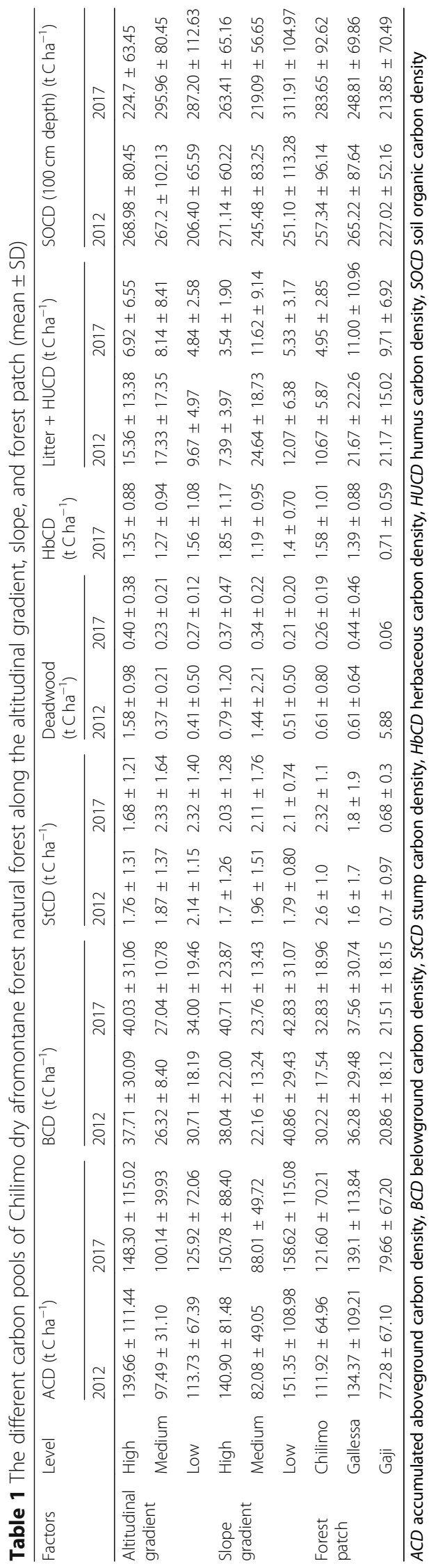


Table 2 ANOVA for the five carbon pools of the Chilimo dry afromontane forest along the altitude, slope, and forest patch

\begin{tabular}{|c|c|c|c|c|c|c|}
\hline Parameters & Factor & DF & Sum square & Mean square & $F$ value & $\operatorname{Pr}>F$ \\
\hline \multicolumn{7}{|c|}{ Aboveground biomass } \\
\hline \multirow[t]{5}{*}{$\mathrm{ACD}\left(\mathrm{t} C h \mathrm{~h}^{-1}\right)$} & Forest patch & 2 & 10,257 & 10,128 & 1.97 & 0.1480 \\
\hline & Altitude class & 2 & 33,432 & 16,716 & 3.25 & $0.0454^{*}$ \\
\hline & Slope class & 2 & 97,753 & 48,877 & 9.51 & $0.0025^{* * *}$ \\
\hline & Time & 1 & 930 & 930 & 0.18 & 0.67211 \\
\hline & Residuals & 62 & 318,701 & 5140 & & \\
\hline \multicolumn{7}{|c|}{ Belowground biomass } \\
\hline \multirow[t]{5}{*}{$\mathrm{BCD}\left(\mathrm{t} C h \mathrm{ha}^{-1}\right)$} & Forest patch & 2 & 1477 & 739 & 1.97 & 0.1480 \\
\hline & Altitude class & 2 & 2438 & 1219 & 3.25 & $0.0454^{*}$ \\
\hline & Slope class & 2 & 7126 & 3563 & 9.51 & $0.0025^{* * *}$ \\
\hline & Time & 1 & 68 & 58 & 0.18 & 0.6721 \\
\hline & Residuals & 62 & 23,233 & 375 & & \\
\hline \multicolumn{7}{|l|}{ Stump biomass } \\
\hline \multirow[t]{5}{*}{$\mathrm{StCD}\left(\mathrm{N} \mathrm{ha}^{-1}\right)$} & Forest patch & 2 & 8.31 & 4.16 & 2.83 & 0.0475 \\
\hline & Altitude class & 2 & 6.13 & 3.06 & 2.09 & 0.1337 \\
\hline & Slope class & 2 & 9.97 & 4.97 & 3.39 & $0.0405^{*}$ \\
\hline & Period & 1 & 0.45 & 0.45 & 0.30 & 0.5834 \\
\hline & Residuals & 57 & 83.77 & 1.47 & & \\
\hline \multicolumn{7}{|l|}{ Deadwood biomass } \\
\hline \multirow[t]{5}{*}{ DWCD $\left(C \mathrm{tha}^{-1}\right)$} & Forest patch & 2 & 11.88 & 5.94 & 6.88 & $0.00401^{* *}$ \\
\hline & Altitude class & 2 & 0.97 & 0.49 & 0.56 & 0.57642 \\
\hline & Slope class & 2 & 0.26 & 0.13 & 0.15 & 0.86325 \\
\hline & Time & 1 & 3.26 & 3.26 & 3.77 & 0.06314 \\
\hline & Residuals & 26 & 22.46 & 0.86 & & \\
\hline \multicolumn{7}{|l|}{ Herbaceous biomass } \\
\hline \multirow[t]{4}{*}{$\mathrm{HbCD}\left(\mathrm{Ctha}{ }^{-1}\right)$} & Forest patch & 2 & 3.31 & 1.66 & 2.07 & 0.0146 \\
\hline & Altitude class & 2 & 3.59 & 1.80 & 2.25 & 0.1250 \\
\hline & Slope class & 2 & 2.50 & 1.25 & 1.57 & 0.2270 \\
\hline & Residuals & 27 & 21.58 & 0.80 & & \\
\hline \multicolumn{7}{|c|}{ Humus and litter biomass } \\
\hline \multirow[t]{5}{*}{$\operatorname{HUCD}\left(\mathrm{t} C \mathrm{ha}^{-1}\right)$} & Forest patch & 2 & 765 & 382.4 & 4.007 & $0.02555^{*}$ \\
\hline & Altitude class & 2 & 321 & 160.3 & 1.680 & 0.19870 \\
\hline & Slope class & 2 & 607 & 303.3 & 3.178 & 0.055187 \\
\hline & Period & 1 & 804 & 804.0 & 8.423 & $0.00588^{* *}$ \\
\hline & Residuals & 42 & 4009 & 95.4 & & \\
\hline \multicolumn{7}{|l|}{ Soil organic carbon } \\
\hline \multirow[t]{7}{*}{$\operatorname{SOCD}\left(\mathrm{t} C h a^{-1}\right)$} & Forest patch & 2 & 76,044 & 38,022 & 13.992 & $1.67 \mathrm{e}-06^{* * *}$ \\
\hline & Altitude class & 2 & 230,462 & 115,231 & 42.403 & $<2 \mathrm{e}-16^{* * *}$ \\
\hline & Land-use type & 3 & 330,301 & 110,100 & 40.515 & $<2 \mathrm{e}-16^{* * *}$ \\
\hline & Slope class & 2 & 11,857 & 5928 & 2.182 & 0.115 \\
\hline & Depth & 3 & 860,002 & 286,007 & 105.489 & $<2 \mathrm{e}-16^{* * *}$ \\
\hline & Time & 1 & 538 & 538 & 0.198 & 0.657 \\
\hline & Residuals & 266 & 722,855 & 2717 & & \\
\hline
\end{tabular}


Table 2 ANOVA for the five carbon pools of the Chilimo dry afromontane forest along the altitude, slope, and forest patch (Continued)

\begin{tabular}{|c|c|c|c|c|c|c|}
\hline Parameters & Factor & DF & Sum square & Mean square & $F$ value & $\operatorname{Pr}>F$ \\
\hline \multicolumn{7}{|c|}{ Total ecosystem carbon } \\
\hline \multirow[t]{5}{*}{ TECD $\left(\mathrm{t} C \mathrm{ha}^{-1}\right) \mathrm{NF}$} & Forest patch & 2 & 3867 & 1934 & 0.08 & 0.9255 \\
\hline & Altitude class & 2 & 133,008 & 66,504 & 2.67 & 0.0775 \\
\hline & Slope class & 2 & 588,092 & 294,046 & 11.79 & $4.59 e-05^{* * *}$ \\
\hline & Time & 1 & 1455 & 1455 & 0.06 & 0.8099 \\
\hline & Residuals & 62 & $1,546,631$ & 24,946 & & \\
\hline
\end{tabular}

Where: $A C D$ Above ground carbon density, DF Degree of freedom, HbCD Herbaceous carbon density, StCD Stump carbon density, DWCD Dead wood carbon density, NF Natural forest, HUCD Humus carbon density, SOCD Soil organic carbon density, $t C h a^{-1}$ tone carbon per hectare, and TECD Total ecosystem carbon density

the highest altitudinal gradients and the lowest for the medium altitudinal gradients in all the measurement times. The mean aboveground and belowground biomass in 2012 for the natural forest was ranged from $139.66 \pm 111.44$ and $37.71 \pm 30.09$ for high altitude to $97.49 \pm 31.10$ and $26.32 \pm 8.40$ for middle altitude, and in 2017, it was ranged from $148.30 \pm 115.02$ and $40.03 \pm$ 31.06 for high altitude to $100.14 \pm 39.93$ and $27.04 \pm$ 10.78 for middle altitudinal gradient. The mean ACD and BCD was also highest at $151.35 \pm 108.98 \mathrm{tC} \mathrm{ha}^{-1}$ for gentle slope and lowest at $88.01 \pm 49.72 \mathrm{t} \mathrm{Cha}^{-1}$ for middle slope. In a similar way, the $\mathrm{ACD}$ and $\mathrm{BCD}$ were highest for Gallessa forest patch and lowest for Gaji forest patch in all the measurement times. Overall, the ACD and BCD affirmed temporal variations among altitudinal gradient and slope (Fig. 3b, c).

\section{Stump carbon biomass}

The stump carbon density of the natural forest varied significantly along slope range and forest patch at $P \leq$ 0.05 . However, it was non-significant among the altitudinal gradient and time (Table 2). The mean stump carbon density $2.38 \pm 1.45$ was highest for the middle altitudinal gradient and $1.81 \pm 1.03 \mathrm{tCha}^{-1}$ was lowest for the highest altitudinal gradient. Stump carbon density also decreased along with the increasing and decreasing altitudinal gradients and slope range. The mean stump carbon density $2.33 \pm 1.64 \mathrm{tC} \mathrm{ha}^{-1}$ was highest for the middle slope and $1.68 \pm 1.21 \mathrm{tC} \mathrm{ha}^{-1}$ was lowest for the steep slope range. The mean stump carbon density 2.32 $\pm 1.1 \mathrm{tCha}^{-1}$ for the Chilimo forest patch was always the highest, while $0.68 \pm 0.3 \mathrm{tCha}^{-1}$ for the Gaji forest patch was the lowest. The stump carbon density was also higher in 2017 than in 2012. Moreover, stump carbon density was influenced by the altitudinal gradient, slope percent, and forest patch (Fig. $4 \mathrm{a}-\mathrm{c}$ ). The stump carbon density among the middle and highest altitudinal gradient was non-significant. The stump carbon density in the Gaji forest patch with others and gentle slope with other slopes were also significant (Fig. 4a, c).

\section{Harbaceous carbon biomass}

The analysis of variance for herbaceous carbon density revealed significant variations among the forest patch $P \leq 0.05$; however, it was non-significant among the altitudinal gradient and slope percent (Table 2). The mean $1.56 \pm 1.08 \mathrm{tCha}^{-1}$ herbaceous carbon density was the highest under the lowest altitudinal gradient, while 1.27 $\pm 0.94 \mathrm{t} \mathrm{C} \mathrm{ha}^{-1}$ was the lowest under the middle altitudinal gradient. Moreover, the herbaceous carbon density showed an increasing trend along with increasing slope percentage (Table 4). The highest herbaceous carbon density was found under the Chilimo forest patch, whereas the lowest was found under the Gaji forest patches (Table 4). The herbaceous carbon density along the altitudinal gradient, slope percent, and forest patch is also presented under Fig. 5a-c. There was also a significant variation among the Gaji forest patch with Chilimo and Gallessa; however, it was non-significant among the altitudinal gradient and slope percent (Fig. 5a-c).

\section{Deadwood carbon pool}

The analysis of variance for deadwood carbon density is presented in Table 1 and non-significant among altitudinal gradient and slope percent at $P \leq 0.05$ (Table 2). The highest $1.58 \pm 0.98 \mathrm{tCha}^{-1}$ deadwood carbon density was found under the highest altitudinal gradient, while the lowest $0.37 \pm 0.21 \mathrm{tC} \mathrm{ha}^{-1}$ was found under the lowest altitudinal gradient. Moreover, there was an increasing trend along with an increasing altitudinal gradient. The highest $1.44 \pm 2.21 \mathrm{tCha}^{-1}$ deadwood carbon density was found under the middle slope range, and the lowest 0.21 $\pm 0.20 \mathrm{tC} \mathrm{ha}^{-1}$ was found under the lowest slope range. Altitude, slope, and forest patch significantly influenced the deadwood carbon density of Chilimo dry afromontane forest at $P \leq 0.05$. In line with, the highest 5.88 $\mathrm{tCha}^{-1}$ deadwood carbon density was found under the Gaji forest patch; however, the lowest $0.26 \pm 0.19$ $\mathrm{tCha}^{-1}$ was found under the Chilimo forest patch (Table 3; Fig. 6c). 
Table 3 Soil organic carbon density (SOCD) (t C ha ${ }^{-1}$ ) along land use types

\begin{tabular}{|c|c|c|c|c|c|c|c|c|c|c|}
\hline Plot no. & LUT & Patch & SOCD.10.2012 & SOCD.10.2017 & SOCD.30.2012 & SOCD.30.2017 & SOCD.50.2012 & SOCD.50.2017 & SOCD.100.2012 & SOCD.100.2017 \\
\hline 1 & $\mathrm{CU}$ & Chilimo & 26.4 & 64.8 & 51.1 & 112.03 & 66.4 & 142 & 90.9 & 223.15 \\
\hline 2 & $\mathrm{CU}$ & Chilimo & 30 & 5.98 & 76.17 & 11.68 & 103.7 & 15.7 & 156.2 & 81.68 \\
\hline 3 & $\mathrm{CU}$ & Chilimo & 28.8 & 24.48 & 74.97 & 54.12 & 109 & 107 & 156.2 & 187.29 \\
\hline \multicolumn{3}{|c|}{ Mean \pm cultivated land } & $28.4 \pm 1.8$ & $31.75 \pm 30.1$ & $67.41 \pm 14.1$ & $59.28 \pm 50.37$ & $93.03 \pm 23.2$ & $88.44 \pm 65.4$ & $134.45 \pm 37.7$ & $164.04 \pm 73.6$ \\
\hline 1 & $\mathrm{DL}$ & Chilimo & 14.94 & 13.39 & 34.83 & 21.95 & 48.33 & 39 & 58.83 & 57.05 \\
\hline 2 & $\mathrm{DL}$ & Chilimo & 6.37 & 3.13 & 16.27 & 7.81 & 21.88 & 9.3 & 26.68 & 12.1 \\
\hline 3 & $\mathrm{DL}$ & Chilimo & 18.24 & 0.96 & 26.16 & 4.92 & 29.68 & 6.84 & 33.28 & 8.79 \\
\hline \multicolumn{3}{|c|}{ Mean \pm degraded land } & $13.28 \pm 6.1$ & $5.83 \pm 6.6$ & $25.75 \pm 9.3$ & $11.56 \pm 9.1$ & $33.30 \pm 13.6$ & $18.38 \pm 17.9$ & $39.60 \pm 17$ & $25.98 \pm 7.0$ \\
\hline 1 & PF & Chilimo & 46.2 & 44.2 & 98.64 & 111.23 & 133.2 & 142 & 157.2 & 209.21 \\
\hline 2 & PF & Chilimo & 74.48 & 63.6 & 160.59 & 84.58 & 184.4 & 118 & 216.8 & 141.82 \\
\hline 3 & PF & Chilimo & 24.29 & 38.3 & 50.21 & 88.92 & 67.1 & 123 & 94.33 & 162.96 \\
\hline 4 & PF & Chilimo & 71.2 & 71.82 & 141.4 & 155.12 & 186.2 & 188 & 228.4 & 222.94 \\
\hline 5 & PF & Chilimo & 53 & 47.3 & 106.46 & 96.8 & 135.3 & 146 & 178.2 & 209 \\
\hline 6 & PF & Chilimo & 59 & 43.46 & 188.96 & 108.36 & 246.1 & 143 & 296.1 & 164.74 \\
\hline 7 & PF & Chilimo & 40.8 & 71.24 & 88.3 & 111.72 & 104.5 & 139 & 122 & 195.33 \\
\hline 8 & PF & Chilimo & 42.4 & 6.72 & 82.14 & 109.76 & 99.42 & 119 & 121.4 & 186.03 \\
\hline 9 & PF & Chilimo & 40.16 & 27.16 & 80.66 & 70.72 & 112 & 161 & 147 & 247.5 \\
\hline \multicolumn{3}{|c|}{ Mean \pm plantation forest } & $50.17 \pm 16$ & $45.98 \pm 21.2$ & $110.82 \pm 44.2$ & $104.13 \pm 23.8$ & $140.90 \pm 55.3$ & $142.11 \pm 22.07$ & $173.49 \pm 63.1$ & $193.28 \pm 33.1$ \\
\hline 1 & NF & Chilimo & 67.03 & 72.19 & 138.89 & 112.28 & 192.4 & 147 & 217.5 & 199.09 \\
\hline 2 & NF & Chilimo & 87.12 & 26.75 & 207.86 & 90.11 & 283.4 & 132 & 372.6 & 194.35 \\
\hline 3 & NF & Chilimo & 27.3 & 49.8 & 92.1 & 150.6 & 139.6 & 233 & 195.4 & 278.92 \\
\hline 4 & NF & Chilimo & 83.79 & 64.98 & 135.89 & 137.67 & 148.7 & 195 & 167.9 & 222.09 \\
\hline 5 & NF & Chilimo & 77.4 & 88.9 & 145.69 & 221.98 & 187.5 & 296 & 213.8 & 428.92 \\
\hline 8 & NF & Chilimo & 100.35 & 86.44 & 273.15 & 184.36 & 357.5 & 235 & 451.5 & 256.68 \\
\hline 11 & NF & Chilimo & 47.31 & 83.79 & 148.11 & 184.59 & 233.6 & 210 & 297.4 & 264.42 \\
\hline 14 & NF & Chilimo & 44.8 & 102.4 & 87.49 & 279.04 & 112 & 358 & 150.5 & 452.45 \\
\hline 17 & NF & Chilimo & 70.66 & 70.66 & 132.48 & 132.48 & 174.7 & 175 & 209.8 & 209.82 \\
\hline 20 & NF & Chilimo & 62.3 & 131.67 & 176.6 & 209.28 & 226.8 & 275 & 297 & 329.78 \\
\hline \multicolumn{3}{|c|}{ Mean \pm SD } & $66.81 \pm 22.0$ & $77.76 \pm 28.6$ & $153.83 \pm 54.8$ & $170.24 \pm 56.9$ & $205.62 \pm 73.2$ & $225.58 \pm 69.9$ & $257.34 \pm 96.1$ & $283.65 \pm 92.6$ \\
\hline 21 & NF & Gallessa & 40.8 & 136.8 & 80.32 & 202.16 & 106.3 & 258 & 130.8 & 305.86 \\
\hline 23 & NF & Gallessa & 78.38 & 99.81 & 215.18 & 225.81 & 272.3 & 245 & 313.1 & 301.51 \\
\hline 25 & NF & Gallessa & 50 & 82.5 & 153.6 & 244.68 & 184 & 263 & 223.2 & 288.69 \\
\hline 28 & NF & Gallessa & 83.3 & 46.4 & 171.46 & 79.84 & 228.6 & 112 & 316.3 & 192.76 \\
\hline 30 & NF & Gallessa & 76.3 & 27.5 & 222.22 & 73.58 & 288.6 & 103 & 342.6 & 155.24 \\
\hline \multicolumn{3}{|c|}{ Mean \pm SD NF Gallessa } & $65.76 \pm 19.0$ & $78.60 \pm 43.3$ & $168.56 \pm 57.2$ & $165.21 \pm 82.2$ & $215.97 \pm 73.60$ & $196.30 \pm 81.33$ & $265.22 \pm 87.64$ & $248.81 \pm 69.86$ \\
\hline 32 & NF & Gaji & 85.4 & 47.6 & 182.68 & 98.37 & 208.6 & 122 & 235.6 & 160.1 \\
\hline 34 & NF & Gaji & 50.4 & 85.2 & 151.2 & 141.36 & 211.4 & 178 & 274.4 & 293.66 \\
\hline 35 & NF & Gaji & 48.55 & 60.09 & 117.67 & 134.39 & 142.3 & 160 & 171.1 & 187.78 \\
\hline \multicolumn{3}{|c|}{ Mean \pm SD NF Gaji } & $61.45 \pm 20.8$ & $64.30 \pm 19.15$ & $150.52 \pm 32.5$ & $124.71 \pm 23.17$ & $187.42 \pm 39.09$ & $153.37 \pm 28.85$ & $227.02 \pm 52.2$ & $213.85 \pm 70.5$ \\
\hline \multicolumn{3}{|c|}{ Mean \pm Natural forest } & $65.62 \pm 19.97$ & $75.75 \pm 30.76$ & $157.37 \pm 50.3$ & $161.25 \pm 60.4$ & $205.46 \pm 66.16$ & $205.41 \pm 70.56$ & $254.48 \pm 84.8$ & $262.34 \pm 83.7$ \\
\hline
\end{tabular}

LUT land-use type, SOCD soil organic carbon density, CU cultivated land, $D L$ degraded land, $P F$ plantation forest, $N F$ naturel forest, $S D$ standard deviation

Humus and litter carbon pools

The humus carbon density of the forest floor along altitudinal gradients was ranged from $17.33 \pm 17.35$ to 4.84 $\pm 2.58 \mathrm{t} \mathrm{Cha}^{-1}$. The analysis of variance also revealed that the humus carbon density was significantly influenced by the forest patch, year of data collected, and slope percent $(P \leq 0.05)$ (Table 2). It was highest for the Gallessa forest patch, but lowest for the Chilimo forest patch (Table 1; Fig. 7c). The highest humus and litter carbon stock density was found 


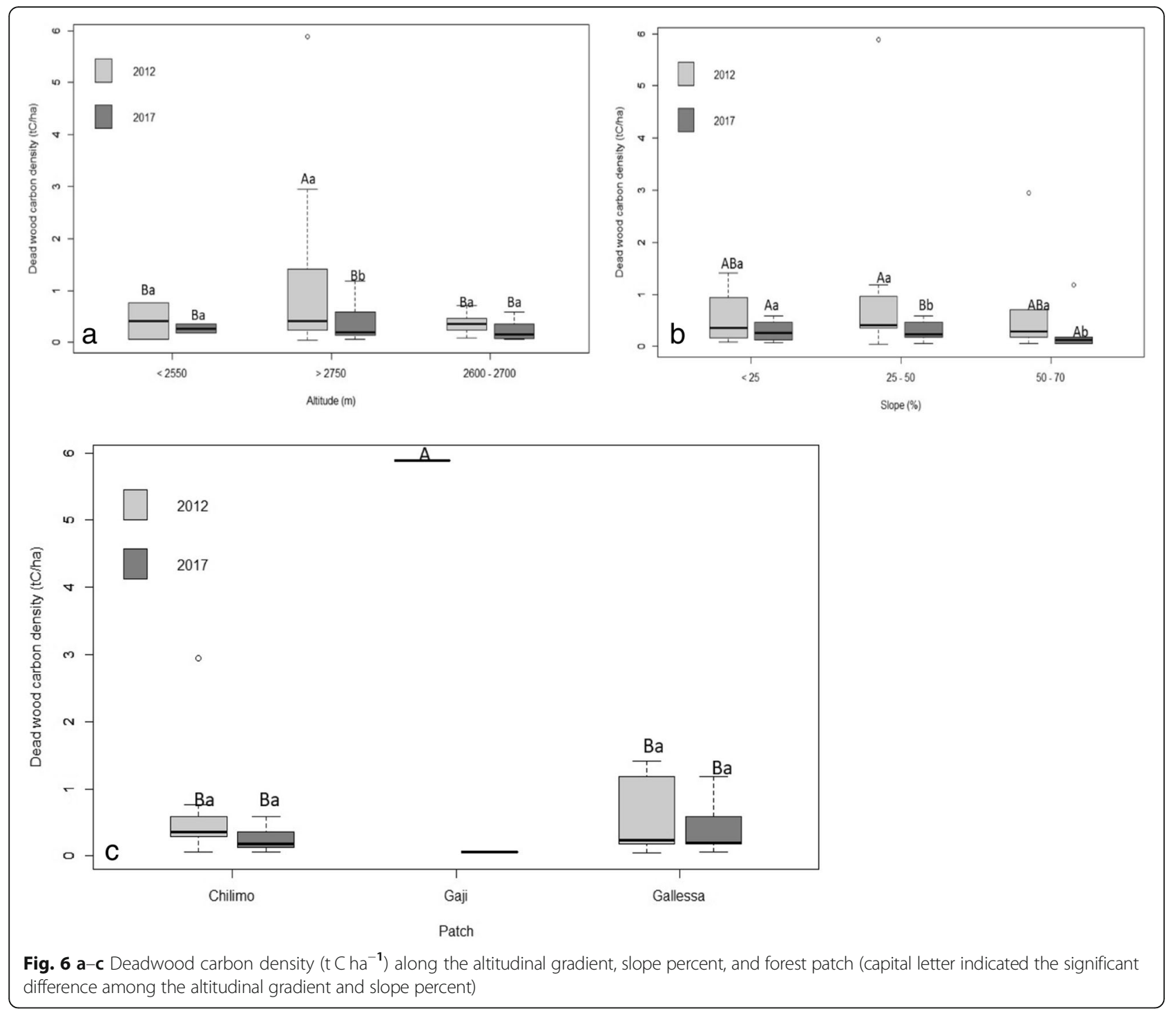

under the middle slope range and showed similar trends with gentle and steep slope ranges (Table 1; Fig. 7b). There was significant difference among middle slope with gentle slope and Gallessa forest patch with Chilimo forest patch; however, it was non-significant among altitudinal gradients and within the same altitudinal gradient (Fig. 7 a-c).

\section{Soil organic carbon pool}

The SOC stock is highly influenced by the altitudinal gradient, slope range, and forest patch. The analysis of variance of soil organic carbon is presented in Table 2 . The SOCD was significantly different among the altitudinal gradient, slope, and land-use types at $P \leq 0.05$. The SOCD up to $1 \mathrm{~m}$ depth was highest at $295.96 \pm 80.45 \mathrm{tC}$ $\mathrm{ha}^{-1}$ under the middle altitudinal gradient, but lowest at
$206.40 \pm 65.59 \mathrm{tC} \mathrm{ha}^{-1}$ under the lower altitudinal gradient (Additional file 1: Table S1; Fig. 9).

The SOCD up to $1 \mathrm{~m}$ depth of the forest patch ranged from $283.65 \pm 92.62$ for the Chilimo forest patch to $213.85 \pm 70.49 \mathrm{tC} \mathrm{ha}^{-1}$ for the Gaji forest patch (Table 1; Fig. 10b). SOCD among the Chilimo and Gallessa forest patch was significant; however, SOCD among the same forest patches with time bound and Gaji forest patch with others was non-significant (Fig. 9b). The SOCD $271.14 \pm 60.22 \mathrm{tC} \mathrm{ha}^{-1}$ in 2012 was the highest under the steep slopes; however, $245.48 \pm 83.25 \mathrm{tC} \mathrm{ha}^{-1}$ was the lowest under the middle slope. In 2017, the SOCD $311.91 \pm 104.97$ was the highest under the gentle slope; however, $245.48 \pm 83.25 \mathrm{tC} \mathrm{ha}^{-1}$ was the lowest under the middle slope. Moreover, the SOCD was also significant among steep slopes and middle slopes; however, it was non-significant among the same slope 

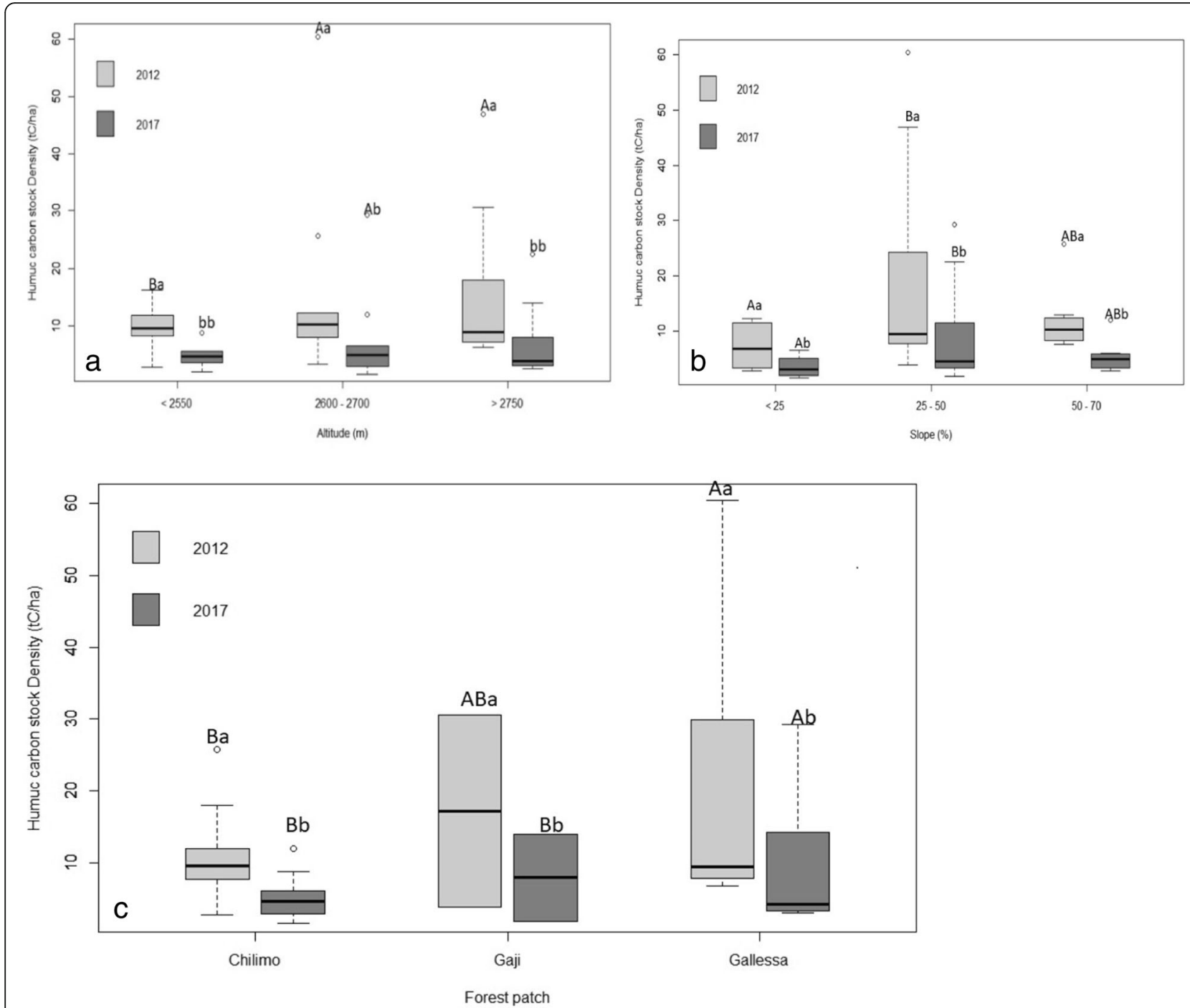

Fig. 7 a-c Humus carbon density $\left(\mathrm{t} \mathrm{Cha}^{-\mathbf{1}}\right.$ ) along the altitudinal gradient, slope percent, and forest patch (capital letter indicated the significant difference among the altitudinal gradient and slope percent)

range with time bound and gentle slope with others, respectively (Fig. 8c).

The soil organic carbon stock density was highly influenced by land-use types and soil depth (Table 2). The SOCD up to $1 \mathrm{~m}$ depth was ranged from 254.48 $\pm 84.8 \mathrm{t} \mathrm{C} \mathrm{ha}^{-1}$ for natural forests to $39.60 \pm 17 \mathrm{t} \mathrm{Cha}^{-1}$ for degraded lands. Similarly, the SOCD in 2017 was ranged from $262.34 \pm 83.7$ for natural forests to 25 $98 \pm 7 \mathrm{tC} \mathrm{ha}^{-1}$ for degraded lands. The mean SOCD up to $1 \mathrm{~m}$ nominal depth of the natural forest was also $264.44 \pm 84.81$ and $277.77 \pm 83.73 \mathrm{tC} \mathrm{ha}^{-1}$ in 2012 and 2017, respectively (Annex 1). the SOCD in the natural forest was always higher than other land-use types in all soil depth. On the contrary, the SOCD in the degraded and cultivated land was the lowest in all soil depth in all the measurement times (Annex 1). Moreover, the SOCD of the natural forest was significantly different among other land-use types and always higher in all soil depth (Table 1 and Fig. 8d). On the contrary, SOCD for the degraded land was the lowest in all soil depth in all the measurement times (Annex 1). The SOCD between the cultivated land and plantation forest was non-significant, although the value of plantation forest was higher than cultivated land. In plantations, the carbon stock density at the same depth was one third less than natural forests but 35\% and 77\% higher than cropland and degraded lands, respectively (Annex 1 ). 

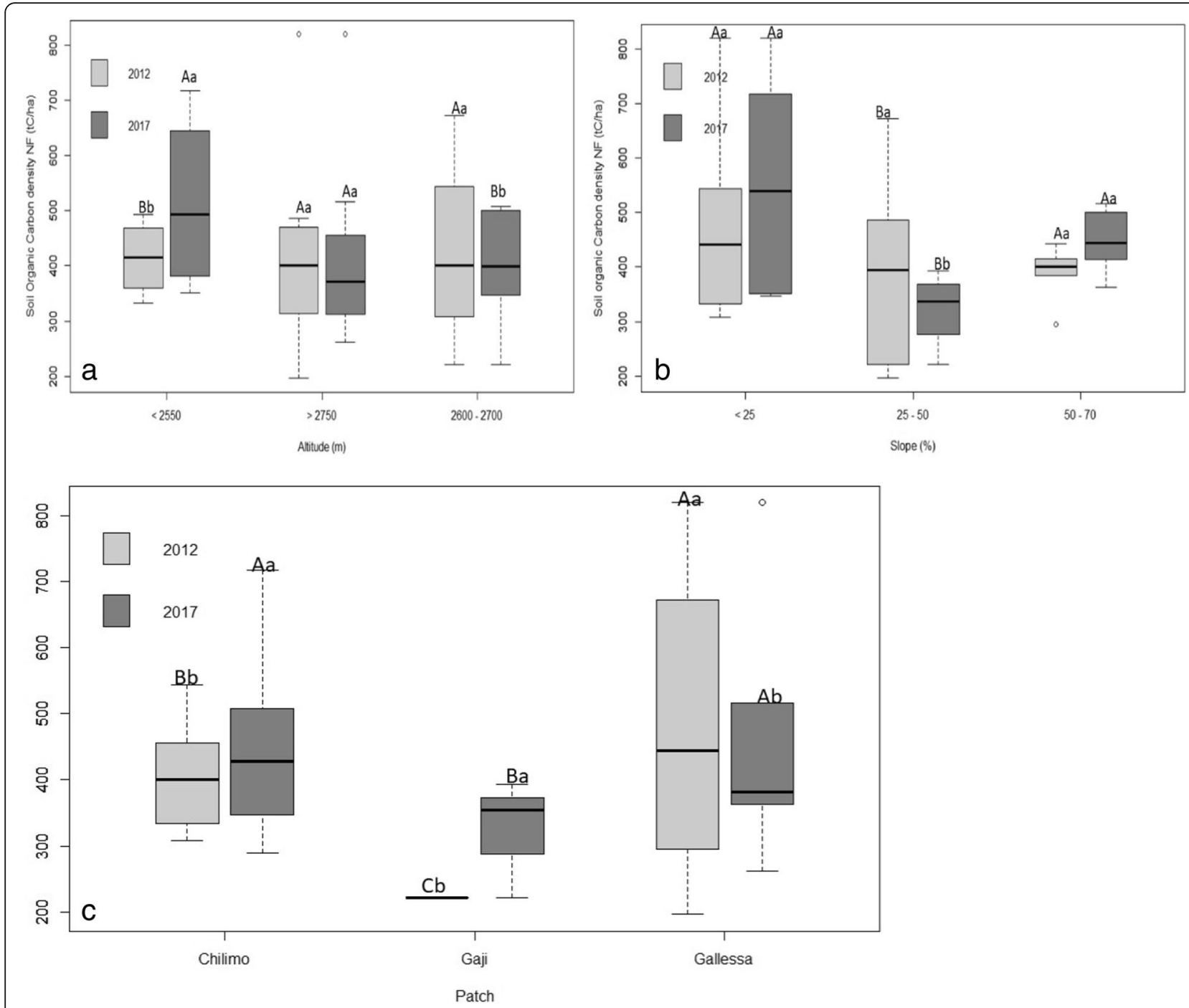

Fig. 8 a-c Soil organic carbon density $\left(\mathrm{t} \mathrm{Cha}^{-\mathbf{1}}\right.$ ) along the altitudinal gradient, slope percent, and forest patch (capital letter indicated the significant difference among the altitudinal gradient and slope percent)

Table 4 The linear regression equation of the different carbon pools of Chilimo dry afromontane forest

\begin{tabular}{|c|c|c|c|c|c|}
\hline$\underline{\mathrm{SN}}$ & Equation & SE & $t$ value & $\operatorname{Pr}>/ t /$ & Adj. $R^{2}$ \\
\hline 1 & HUCD2012 $=-0.6563+41.6202$ DWCD2012 & $\begin{array}{l}0.60 \\
0.21\end{array}$ & $\begin{array}{l}-1.09 \\
34.36\end{array}$ & $\begin{array}{l}0.286 \\
<2 \mathrm{e}-16^{* * *}\end{array}$ & 0.98 \\
\hline 2 & HUCD2017 $=-1.0623+20.5616 \mathrm{HbCD} 2017$ & $\begin{array}{l}0.37 \\
0.74\end{array}$ & $\begin{array}{l}-2.86 \\
27.85\end{array}$ & $\begin{array}{l}0.00887^{* *} \\
<2 \mathrm{e}-16^{* * *}\end{array}$ & 0.97 \\
\hline 3 & HUCD2017 $=-0.6336+20.2528$ DWCD2012 & $\begin{array}{l}0.25 \\
0.49\end{array}$ & $\begin{array}{l}-2.59 \\
41.00\end{array}$ & $\begin{array}{l}0.0166^{*} \\
<2 e-16^{* * *}\end{array}$ & 0.97 \\
\hline 4 & $\mathrm{HbCD} 2017=0.0461198+0.0230173 \mathrm{HUCD} 2012$ & $\begin{array}{l}0.01 \\
0.001\end{array}$ & $\begin{array}{l}3.29 \\
33.20\end{array}$ & $\begin{array}{l}0.00324^{* *} \\
<2 \mathrm{e}-16^{* * *}\end{array}$ & 0.98 \\
\hline 5 & $\mathrm{HbCD} 2017=0.02648+0.97002$ DWCD2012 & $\begin{array}{l}0.01 \\
0.03\end{array}$ & $\begin{array}{l}2.15 \\
39.05\end{array}$ & $\begin{array}{l}0.0424^{*} \\
<2 \mathrm{e}-16^{* * *}\end{array}$ & 0.99 \\
\hline 6 & StCD2012 $=0.25923+0.72541 S t C D 2017$ & $\begin{array}{l}0.18 \\
0.08\end{array}$ & $\begin{array}{l}1.461 \\
9.152\end{array}$ & $\begin{array}{l}0.151 \\
1.4 \mathrm{e}-11^{* * *}\end{array}$ & 0.66 \\
\hline
\end{tabular}



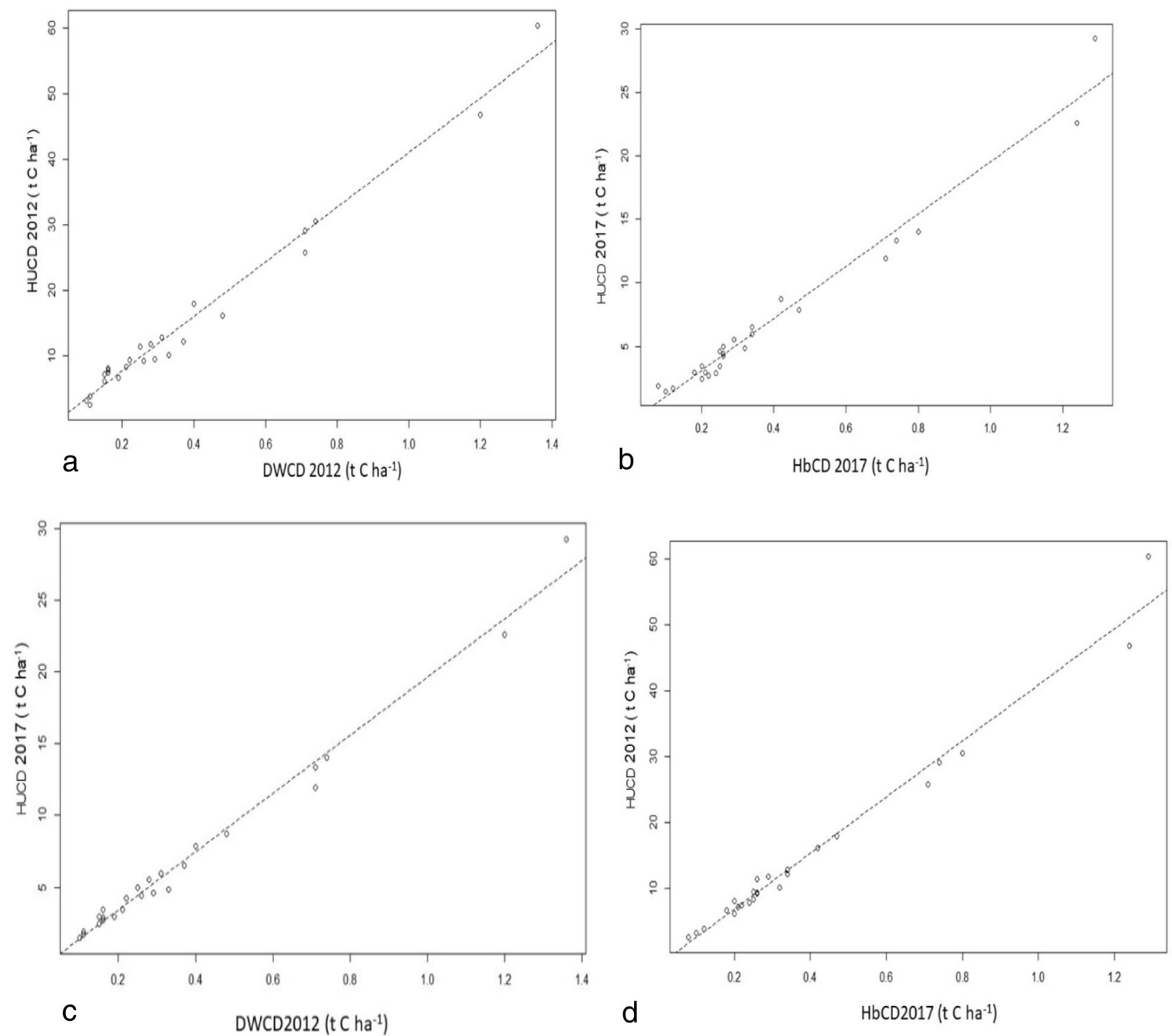

Fig. 9 a The linear relationship between HUCD 2012 and DWCD 2012. b The linear relationship between HUCD 2017 and HbCD 2017. c The linear relationship between HUCD 2017 and DWCD 2012. d The linear relationship between HUCD 2012 and HbCD 2017

\section{Is there any correlation among carbon pools in the natural} forest?

The multiple regression correlation matrix and linear relationship of various carbon pools in the Chilimo forest ecosystem are presented in Table 3 and affirmed the linear relationship among carbon pools. Based on the goodness-of-fit statistics and biological behavior of the model, there was a strong linear relationship between the weighted aboveground, humus, herbaceous, and deadwood carbon density which was highly correlated with the adjusted $R^{2}$ (>0.97) (Tables 3 and 4 ). There was also a moderate linear relationship between the soil organic carbon stock density and the adjusted $R^{2}(>0.60)$. However, there was a weak linear relationship between stump carbon density and topsoil carbon density, aboveground carbon density and herbaceous carbon density, and aboveground carbon density and stump carbon density (Fig. 9a-d).

\section{Do environmental factors and forest patch affect total ecosystem carbon?}

The results affirmed that the total ecosystem carbon was significantly influenced by environmental factors and forest patch at $P \leq 0.05$. The highest total ecosystem carbon stock density was found under the highest altitudinal gradient, highest slopes, and Gallessa forest patch (Fig. $10 \mathrm{a}-\mathrm{c}$ ). The total ecosystem carbon density was significant among the middle and highest altitudinal gradient, the middle slope with steep and gentle slopes, and 

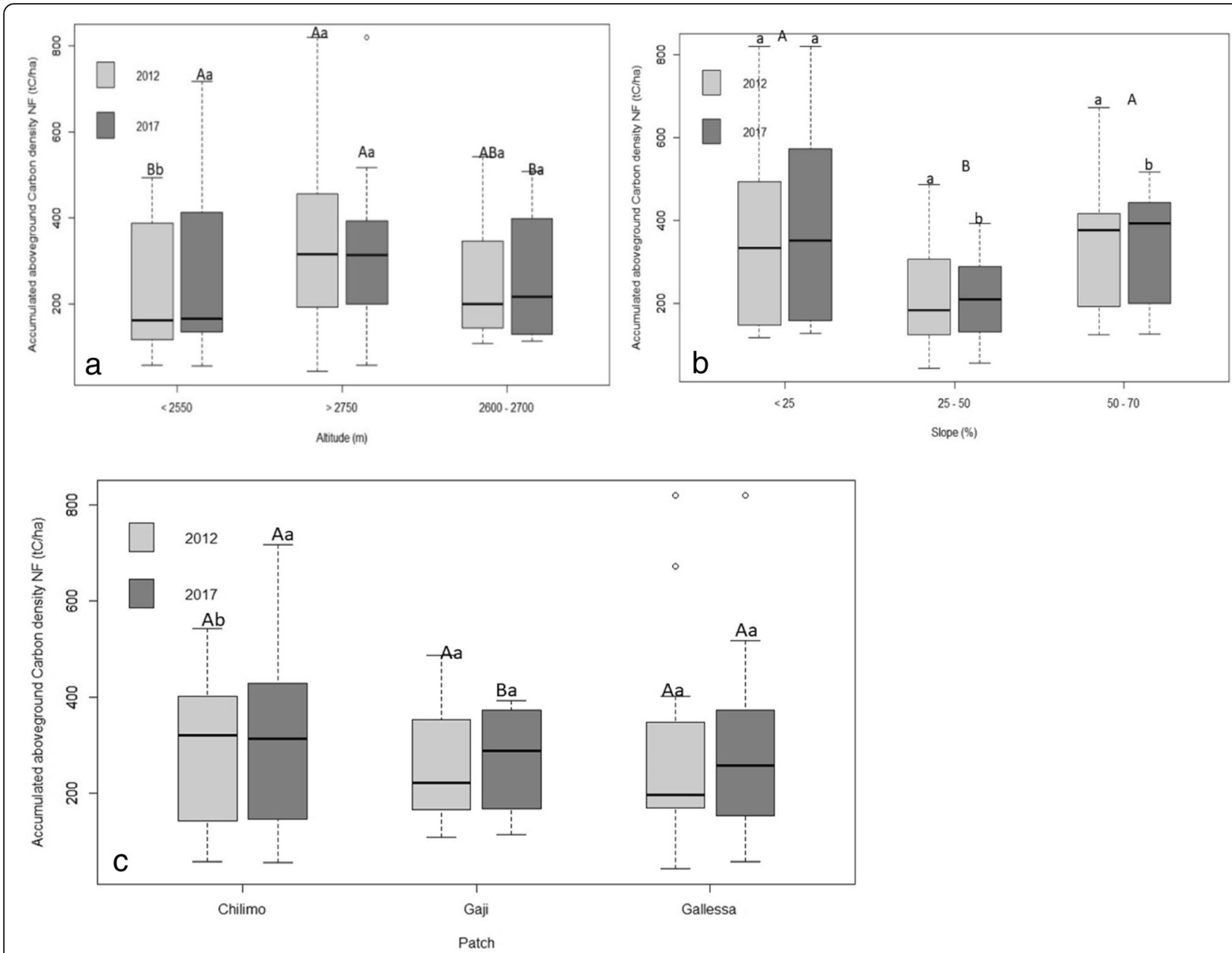

Fig. 10 a-c Total ecosystem carbon density $\left(\mathrm{t} \mathrm{Cha}^{-\mathbf{1}}\right.$ ) along the altitudinal gradient, slope percent, and forest patch (capital letter indicated the significant difference among the altitudinal gradient, slope percent, and forest patch)

the Gaji forest patch with Chilimo and Gallessa forest patches (Fig. $10 \mathrm{a}, \mathrm{b}$ ). The mean ecosystem carbon stock density of the sampled plots in natural forests was also ranged from 196.22 to 672.72 and 221.89 to $819.44 \mathrm{tC}$ $\mathrm{ha}^{-1}$ in 2012 and 2017, respectively (Additional file 1). The total natural forest and plantation forest were estimated to be 5000 and 450 ha, respectively. The sum of the total ecosystem carbon stock density for the natural and planted forest was $1,564,847\left(5,742,996.2 \mathrm{t} \mathrm{CO}_{2}\right.$ eq. in 2012 and 1,660,318 t $\mathrm{C}$ or 6,093,365 $\mathrm{t} \mathrm{CO}_{2}$ eq. in 2017). The combined carbon sequestration potential of the Chilimo natural forest and planted forest was also estimated to be $65,828.98 \mathrm{tCO}_{2}$ eq. year ${ }^{-1}$. The carbon sequestration potential of the Chilimo natural and planted forest was estimated to be $65,828.98 \mathrm{CO}_{2}$ eq. year ${ }^{-1}$.

\section{Discussion}

The present study has investigated the temporal variation in carbon pools of the Chilimo dry afromontane forest along the altitudinal gradient, slope, and forest patch. This study is also the first type in the study area conducted into two consecutive periods. There is a lower aboveground biomass in the middle altitudinal gradient, this is might be due to the intense anthropogenic effect, which resulted in few but big trees with higher above and belowground biomass. In addition, there is a higher stump carbon density in the middle and lower altitudinal gradient, this is might be due to the presence of higher number of stumps. In line with, similar reports were also reported by Shumi (2009), Hassen (20150, Tesfaye (2015), and Tesfaye et al. (2016).

The aboveground biomass carbon density reported $\left(200 \mathrm{tC} \mathrm{ha}^{-1}\right)$ in the Chilimo forest is also higher than the Gara Mukitar dry afromontane forest in Eastern Ethiopia (156.60 $\mathrm{t} \mathrm{Cha}^{-1}$ ) (Wodajo 2018). However, it was less than by 142.47 and $174.02 \mathrm{tC} \mathrm{ha}^{-1}$ of the Arba Minch riverine forest, Egdu forest, and Gera moist afromontane forest (Hassen 2015; Meles et al. 2014; Feyissa 
et al. 2013), Chato forest (301.86 $\mathrm{t} \mathrm{Cha}^{-1}$ ) (Iticha 2017) and Ades forest too $\left(259.17 \mathrm{t} \mathrm{Cha}^{-1}\right)$ (Kassahun et al. 2015). The highest ACD $\left(200 \mathrm{tC} \mathrm{ha}^{-1}\right)$ under the higher altitudinal gradient and slope range is might be due to lower disturbance. Similar findings are also reported for other Ethiopian forests too (Girma et al. 2004; Hassen 2015; Iticha 2017).

The mean accumulated biomass capacity of the Chilimo forest as mentioned above is also in line with the reports of Eticha et al. (2017). But, it was lower than the Zequala Monastery (475.51 $\mathrm{t} \mathrm{Cha}^{-1}$ ) and Semien Mountain National Park forest $\left(994.16 \mathrm{tC} \mathrm{ha}^{-1}\right)$ in the Central and Northern Ethiopia, respectively (Abel Girma et al. 2014; Yelemfrhat et al. 2014). The highest deadwood carbon density at steep slopes and highest altitudinal gradients is might be due to the low disturbance. Moreover, the higher deadwood carbon density in the Gaji forest patch is also due to the presence of big fallen trees in the sampled site than others.

The herbaceous carbon density of the Chilimo forest is in line with other tropical seasonal rain forests (1.4), tropical secondary forests (1.9) (Lasco et al. 2006), and subtropical forest too $\left(2.6-3.8 \mathrm{t} \mathrm{Cha}^{-1}\right.$ ) (Brown et al. 1989). The higher herbaceous carbon density under the lower and higher altitudinal gradients is also might be due to the low canopy cover. The higher herbaceous carbon density in steep slopes is also due to the low disturbance and better nutrient release. Swai et al. (2014) reported low tree density makes a suitable condition for undergrowth, vegetation, and higher precipitation. The reduction in litter and humus carbon is due to an increasing disturbance and excessive removal of litterfall.

The soil carbon stock density was conducted across the altitudinal gradient, land-use type, slope, and forest patch for the last 5 years except a study done by Tesfaye et al. (2016). In this study, the soil carbon stock was significant along the altitudinal gradient as suggested by other studies in African forests too (Zewdu et al. 2004; Twongyirwe et al. 2013), because altitudinal gradient is one of the environmental factors that affect the soil carbon stock density and it can be considered as a useful tool to predict the forest carbon stock (Mayaux et al. 2007). Results of the present study also revealed that higher soil organic carbon stock density was found under the middle altitudinal gradients. This was might be due to low soil erosion and higher number of inputs. However, the carbon stock in the forest floor showed a reduction in the last 5 years. This is might be due to frequent removal of litterfall and twigs by fuelwood collectors. At the same time, lower canopy cover might result in high sunlight to reach the forest floor that accelerates the litter decomposition. Similary, Hassen (2015) found higher carbon pools in Gera moist afromontane forest due to higher disturbance.
The higher carbon stock density in the middle altitudinal gradient is might be due to higher disturbance; this is also in line with Kassahun et al. (2015) who reported for a higher SOC density under a middle altitudinal gradient of Ades dry afromontane forest. The lower carbon stock density in the higher and middle elevation is might be due to the over sealing of soil by livestock movement and higher soil erosion. In addition, there is a continuous removal of fallen litter, deadwood, and twigs by fuelwood collectors. Tree cutting for firewood, charcoal making, illegal logging for timber and construction wood, forest clearing for agricultural land, and free livestock grazing are also frequently occurring in these areas.

Land use is a major factor in carbon stock, among the four land-use types studied in the Chilimo dry afromontane forest and adjacent land uses. The higher carbon stock in the natural and plantation forest in all the sampled period is might be due to higher litterfall, decomposition rate, and species composition. The low erosion rate in the natural and plantation forest was might be due to the interception of the raindrops by plants. The carbon stock density was slightly reduced in the forest floor in the last 5 years due to the lack of appropriate land management practices to improve land productivity and more tree cutting in the natural forest than previous years. The low carbon in the degraded and cultivated land is might be due to the low nutrient cycling, continuous tillage, and crop residue removal for livestock feed in the cultivated land. In addition, in the degraded land, there is an over sealing and surface crusting effect, which reduced the microbial activity and leads to a high runoff and soil erosion. In general, there is a slight increase in the carbon stock in the degraded land in the last 5 years; this is might be due to some exclosure activities done in these areas. Similar results were also reported by several authors; Girmay et al. (2008) reported the carbon stock in the topsoil $(0-10 \mathrm{~cm})$ is decreased after the conversion of native forest into croplands $(-63 \%)$ and plantations $(-83 \%)$. Solomon et al. (2002) indicated that the conversion of humid tropical forests for maize cultivation in Southern Ethiopia resulted in a 55-60\% reduction in SOC stock. Ashagrie et al. (2005) also reported losses of $13 \mathrm{Mg} \mathrm{Cha}^{-1}$ over a period of 21 years in southern Ethiopia when natural forest was converted into a eucalyptus plantation. In Brazil, Zinn et al. (2002) reported a $23-48 \%$ loss in SOC after a native wooded savannah was converted into a eucalyptus plantation. Rhoades et al. (2000) reported a 70\% reduction in SOC in Ecuador in the upper $30 \mathrm{~cm}$ of the topsoil when the original forest was converted into a sugarcane plantation (Saccharum spp.). Berhangaray et al. (2013) investigated the impact of changes in land use on soil carbon stock found under trees than pasture and agricultural lands. In our study, tree 
plantations stored 34\% less carbon than native forest, but the land-use change sequence was different. Plantations were originally planted outside the forest on bare or degraded land. In this situation, tree plantations stored $80 \%$ more carbon than degraded lands and 56.4\% more carbon than croplands. The $\mathrm{C}$ stock density under native natural forest and plantation forest in the Chilimo dry afromontane forest was higher than those reported in other regions (Beets et al. 2002; Harms et al. 2005; Twongyirwe et al. 2013) and suggests two management strategies for improving soil conditions. The first is to maintain and preserve the Chilimo natural forest as other African tropical forests do (Lewis et al. 2009), and the second is to recover abandoned croplands and degraded lands by establishing tree plantations.

There is a strong linear relationship between the humus and herbaceous carbon density due to the presence of higher humus content which is good for the growth of herbaceous plants and higher decomposition rate and open canopy cover. On the contrary, the presence of higher humus content results due to low soil erosion. The strong linear relationship between the humus and deadwood carbon density is might be due to a higher litterfall, better decomposition, and better twigs. The weak linear relationship between the stump and herbaceous carbon density is due to a higher number of stumps, low aboveground carbon density, and lower herbaceous plants.

The total area of Chilimo forest was 22,000 ha in 1982 and reduced to 4500 ha in 2016; as a result, the total carbon emission for Chilimo forest in the last 34 years was $5,218,850 \mathrm{t}$ C. In general, the mean carbon stock density of Chilimo forest has increased from 289.86 to $298.22 \mathrm{t} \mathrm{C}$ $\mathrm{ha}^{-1}$. In 2012, the total ecosystem carbon density was $56.12 \%$ in soil organic carbon, $31.21 \%$ aboveground biomass, $8.43 \%$ belowground biomass, $3.65 \%$ humus carbon, $0.47 \%$ stump carbon, and $0.12 \%$ deadwood carbon. In the same line in 2017, the highest share for ecosystem carbon density was soil organic carbon (59.64\%), aboveground carbon (29.78\%), belowground carbon (8.04\%), humus carbon $(1.69 \%)$, stump carbon $(0.48 \%)$, herbaceous carbon $(0.33 \%)$, and deadwood carbon $(0.04 \%)$, respectively.

\section{Conclusions}

The aboveground and belowground biomass of the Chilimo natural forest was the highest for the highest altitudinal gradients and the lowest for the medium altitudinal gradients in all the measurement times. The stump carbon density was increased in 2017 than in 2012 due to the increasing number of illegal stumps. Deadwood and humus carbon density was reduced by $50 \%$ in the last 5 years due to a surplus increasing level of disturbance. The SOCD up to $1 \mathrm{~m}$ depth was the highest at $295.96 \pm 80.45 \mathrm{tCha}^{-1}$ under the middle altitudinal gradient; however, it was the lowest at 206.40 $\pm 65.59 \mathrm{t} \mathrm{Cha}^{-1}$ under the lower altitudinal gradient. The Chilimo natural forest stored more carbon than adjacent land-use categories, but degraded land stored the lowest soil organic carbon stock. The carbon stock density was weakly correlated among the stump carbon density and aboveground carbon density. The sum of total ecosystem carbon stock density and carbon sequestration potential for the natural and planted forest was $1,660,318 \mathrm{tC}$ or $6,093,365 \mathrm{tCO}_{2}$ eq. and $65,828.98 \mathrm{CO}_{2}$ eq. year ${ }^{-1}$, respectively. For maintaining a higher carbon stock density in the study area, other land use types such as degraded land and cultivated. Forest management options should be applied to improve productivity. We recommend a forest carbon-related awareness creation for local people, and promotion of the local knowledge can be regarded as a possible option for sustainable forest management.

\section{Additional file}

Additional file 1: Table S1. Ecosystem carbon accumulation potential of Chilimo dry afromontane forest 2012 and 2017. (DOCX 47 kb)

\begin{abstract}
Abbreviations
${ }^{\circ} \mathrm{C}$ : Degree Celcius; ACD: Accumulated aboveground carbon density; AGB: Aboveground biomass; ANOVA: Analysis of variance; BCD: Belowground carbon density; C: Carbon; CFW: Coarse fragmented matter; $\mathrm{Cm}$ : Centimeter; $\mathrm{CO}_{2}$ eq: Carbon equivalent; $\mathrm{CO}_{2}$ : Carbon dioxide; $\mathrm{CU}$ : Cultivated land;

Dbh: Diameter at breast height; DL: Degraded land; DWCD: Deadwood carbon density, g: Gram; Gt: Giga tone; H: Height; HbCD: Herbaceous carbon density; HUCD: Humus carbon density; IPCC: International Panel for Climate Change; Km: Kilometer; LCD: Litter carbon density; LUT: Land-use type; M: Meter; Mg: Megagram; mm: Millimeter; NF: Natural forest; PF: Plantation forest; SD: Standard deviation; SOCD: Soil organic carbon density; StCD: Stump carbon density; $\mathrm{t} \mathrm{Cha}^{-1}$ : Tonne carbon per hectare; Tg: Teragram; V: Volume; $\rho:$ Basic wood density
\end{abstract}

\section{Acknowledgements}

The authors thanks Genene Tesfaye, Central Ethiopia Environment and Forest Research Centre, for assisting us in field data collection and preparation of plant and soil samples, Mossissa Kebede from Oromiya Forest and Wildlife Enterprise, Ginch Branch and Mekonnen Gemechu from Chilimo village, for their assistance in field work and soil pit digging.

\section{Funding}

The Ecosystem Management Research Directorate, Ethiopian Environment and Forest Research Institute (EEFRI) for funding the research grant and the Swiss Government Scholarship programme was given full scholarship for funding to Mehari A.Tesfaye's fellowship.

\section{Availability of data and materials}

The data sets used and analyzed during the current study are available from the corresponding author on reasonable request.

\section{Authors' contributions}

MAT contributed to the design of the experiment, data collection and analysis, and writing of the manuscript. OG contributed to the data analysis and commented and edited the manuscript, TB commented and edited the manuscript. JB contributed to the overall supervision of the work and commented and edited the manuscript. All authors read and approved the final manuscript. 


\section{Ethics approval and consent to participate}

This research was performed in accordance with the laws, guidelines and ethical standards of Ethiopia and Switzerland, where the research was performed.

\section{Competing interests}

The authors declare that they have no competing interests.

\section{Publisher's Note}

Springer Nature remains neutral with regard to jurisdictional claims in published maps and institutional affiliations.

\section{Author details}

${ }^{1}$ Ethiopian Environment and Forest Research Institute (EEFRI), Box 24536 code 1000, Gurd Shola, Addis Ababa, Ethiopia. ${ }^{2}$ School of Agricultural, Forest and Food Sciences HAFL, Bern University of Applied Sciences, CH-3052 Zollikofen, Switzerland.

Received: 17 January 2019 Accepted: 21 March 2019

Published online: 09 May 2019

\section{References}

Adugna F, Teshome S, Mekuria A. Forest carbon stocks and variations along altitudinal gradients in Egdu forest: implications of managing forests for climate change mitigation. Sc Technol Art Res J. 2013;2(4):40-6.

Anderson JM, Ingram JS. Tropical soils biology and fertility. A hand book of methods. 2nd ed. Wallingford: CAB, International; 1996.

Ashagrie Y, Zech W, Guggenberg G. Transformation of Podocarpus falcatus dominated natural forest into a monoculture Eucalyptus globulus plantation at Munessa, Ethiopia. Soil organic C, N and S dynamics in primary particle and aggregate-size fractions. Agriculture, ecosystem \& environment, vol. 106; 2005. p. 89-98.

Baccini A, Laporte N, Goetz SJ, Sun M, Dong H. A first map of Africa's above ground biomass derived from satellite imagery. Environ Res Lett. 2008;3: 045011. https://doi.org/10.1088/1748-9326/3/4/045011.

Baker DF. Reassessing carbon sinks. Science. 2007;316:1708-9.

Beets PN, Oliver GR, Clinton PW. Soil carbon protection in podocarp/hardwood forest and effects of conversion to pasture and exotic pine forest. Environ Pollut. 2002;116:S63-73 PMID: 11833919 (PubMed- Indexed for MEDLINE).

Bekele M. Forest property rights, the role of the state and institutional exigency: the Ethiopian experience. Doctoral Thesis. Uppsala: Swedish University of Agricultural Sciences; 2003.

Bekele M. Forest property rights, the role of the state and institutional exigency: the Ethiopian experience. Doctoral Thesis. Uppsala: Swedish University of Agricultural Sciences; 2004.

Ben-Dar E, Banin A. Determination of organic matter in arid-zone soils using a simple loss-on-ignition method. Commun Soil Sci Plant Anal. 1989;20(15-16). https://doi.org/10.1080/100103622890936175.

Berhangaray G, Alvare R, de Paepe J, Caride C, Cantet R. Land use effects on soil carbon in argentine pampas. Geoderma. 2013;192:97-110 https://doi.org/10. 1016/j.geoderma.2012.07.016.

Bhat J, lqbal K, Kumar M, Negi A, Todaria N. Carbon stock of trees along an elevational gradient in temperate forests of Kedarnath Wildlife Sanctuary. For Sci Pract. 2013;15(2):137-43.

Blake GR. Bulk density. In: Black CA, editor. Methods of soil analysis. Wisconsin: American Society of Agronomy; 1965. p. 374-90.

Bongers F, Tenngkeit T. Degraded forests in Eastern Africa: introduction. In: Bongers F, Tenningkeit T, editors. Degraded forests in Eastern Africa: management and restoration. London: Earthscan Ltd; 2010. p. 1-18.

Brown S. Estimating biomass and biomass changes of tropical forests: a primer: FAO forestry paper 134. United Nations, Rome: FAO; 1997.

Brown SAJ, Gillespie JR, Lugo AE. Biomass estimation methods for tropical forests with application to Forest inventory data. For Sci. 1989;35(4):881-902.

Chave J, Réjou-Méchain M, Búrquez A, Chidumayo E, Colgan MS, WBC D, Vieilleden G. Improved allometric models to estimate the aboveground biomass of tropical trees. Glob Chang Biol. 2014;20:3177-90. https://doi. org/10.1111/gcb.12629.

Chave J, Rieâra B, Dubois M. Estimation of biomass in a neotropical forest of French Guiana: spatial and temporal variability. J Trop Ecol. 2001;17:79-96.

Chidumayo E, Okali D, Kowero G, Lrwanou M. Climate change in African forest and wildlife resources. Nairobi: African Forest Forum; 2011.
De Vos B, Vandecasteele D, Deckers J, Muys B. Capability of loss on ignition as a predictor of total organic carbon in non - calcareous forest soils. Commun Soil Sci Plan Anal. 2005;36:2899-921.

Desalegn G, Abega M, Teketay D, Gezahgne A. Commercial timer species in Ethiopia: characteristics and uses-a handbook for forest industries, construction and energy sectors, foresters and other stakeholders. Addis Ababa: Addis Ababa University Press; 2012.

Diawei L, Zongmin W, Bia Z, Kaishan S, Xiaoyan L, Jiaoyan L, Jiaping L, Fang L, Hongatao D. Spatial distribution of soil organic carbon and analysis of related factors in croplands of the black soil regions, Northeast China, agriculture, ecosystems and environment, vol. 113; 2006. p. 73-81.

EMA. National atlas of Ethiopia. Addis Ababa: Ethiopian Mapping Authority; 1988. p. 76.

FAO (Food and Agricultural Organization of the United Nations). Global forest resource assessment. FAO forestry paper 147. Rome: Food and Agriculture Organization of the United Nations; 2005.

Gebre TM. Biomass and soil carbon stocks along elevation gradeints of woodland ecosystems. The case of Liben district, South Ethiopia: WGCF, Shashemene, Ethiopia; 2015. MSc Thesis

Gibbs HK, Brown S, Niles JO, Foley JA. Monitoring and estimating tropical forest carbon stocks: making REDD a reality. Environ Res Lett. 2007;2:045023.

Girma A, Soromessa T, Bekele T. Forest carbon stocks in woody plants of mount Zequalla Monastery and its variation along altitudinal gradient : implication of managing forests for climate change mitigation. Sci Technol Arts Res J. 2004;3(2):133-41.

Girma A, Soromessa T, Bekele T. Forest carbon stocks in woody plants of mount Zequalla Monastery and its variation along altitudinal gradient: implication of managing forests for climate change mitigation. Sci Technol Arts Res J. 2014;3(2): $132-40$.

Hamere Y, Teshome S, Mekuria A. Carbon stock analysis along slope and slope aspect gradient in Gedo Forest : implications for climate change mitigation. J Earth Sci Clim Chang. 2015;6:9.

Harms BP, Dalal RC, Cramp AP. Changes in soil carbon and soil nitrogen after tree clearing in the semi-arid range lands of Queensland. Aust J Bot. 2005;53: 639-50. https://doi.org/10.1071/BT04154.

Hassen N. Carbon stock along altitudinal gradient in Gera Moist Evergreen Afromontane forest. MSc Thesis, AAU, Addis Ababa, Ethiopia: South Western Ethiopia; 2015.

Houghton RA. The annual net flux of carbon to the atmosphere from changes in land use 1850-1990. Tellus B. 1998;51:298-313.

IPCC. Good practice guidance for land-use change and forestry. In: Penman J, Gytarsky M, Hiraishi T, Krup T, Kruger D, Pipatti R, Buendia L, Miwa K, NigaraT TK, Wagner F, editors. IPCC, National Greenhouse Gas Inventories Program. Japan: Published by the Institute of Global Environmental Strategies (IGES); 2003.

IPCC. In: Egsleston HS, Buendia L, Miwa K, Ngaran T, Tanabe K, editors. Guidelines for national greenhouse gas inventories (vol 4, AFOLU). National Greenhouse Gas Inventories Program. Japan: Published; IGES; 2006.

IPCC. Climate change 2007: mitigation of climate change. In: Metz B, Davidson OR, Bosch PR, Dave R, Meyer LA, editors. Contribution of working group III to the $4^{\text {th }}$ assessment report of the intergovernmental panel on climate change. Cambridge: Cambridge University Press; 2007. p. 851.

IPCC. In: Stocker TF, Qin D, Plattner G-K, Tignor M, Allen SK, Boschung J, Nauels A, Xia Y, Bex V, Midgley PM, editors. Climate change 2013: the physical science basis. contribution of working group I to the 5 th assessment report of the intergovernmental panel on climate change. United Kingdom and New York: Cambridge University Press, Cambridge; 2013. p. 1535. https://doi.org/10. 1017/CBO9781107415324.

Iticha B. Ecosystem carbon storage and partitioning in Chato afromontane forest. Its climate change mitigation and economic potential. Int J Environ Agric Biotechnol. 2017;2(4):2450-1878.

Kangas A, Maltamo M. Forest inventory methodology and applications : managing forest ecosystems 10. Dordrecht: Springer; 2006.

Kassa AG (2015) Forest carbon stock and variations along environmental gradients in Yeka forest and its implication for climate change mitigation. MSC Thesis, AAU, Graduate progarmme.

Kassa H, Campbell B, Sandewall M, Kebede K, Tesfaye Y, Dessie G, Seifu A, Tadesse M, Garedewe E, Sandwall K. Building future scenarios and covering persisting challenges of participatory forest management in Chilimo forest, Central Ethiopia. J Environ Manag. 2008. https://doi.org/10.1016/j.jenuman. 2008.03.2009.

Kassahun K, Soromessa T, Belliethathan S. Forest carbon stock in woody plants of Ades Forest, Western Haraghae zone of Ethiopia and its variation along 
environmental factors: implications for climate change mitigation. J Nat Sci Res. 2015;5(21) www.iiste.org.

Kelbessa E, Soromessa T. Biodiversity, ecological and regeneration studies in Bonga, Borana and Chilimo forests. Technical report prepared for Farm Africa-SoS-Sahel. Addis Ababa: Addis Ababa University; 2004.

Köhl M, Magnussen SS, Marchett M. Sampling methods, remote sensing and GIS multi resource forest inventory. Berlin Heidelberg: SpringerVerlag; 2006.

Lal R. Soil carbon sequestration to mitigate climate change. Geoderma. 2004;123:1-22.

Lal R. Forest soils and carbon sequestration. For Ecol Manage. 2005;220(1-3):242-52. https://doi.org/10.1016/j.foreco.2005.08.015.

Lamprecht H. Silviculture in the tropics. Tropical forest ecosystems and their tree species-possiblities and methods for their long term utilization. Eschborn: Technical Cooperation-Federal Republic of Germany; 1989.

Lasco RD, MacDicken KG, Pulhin FB, Guillermo IQ, Sales RF, Cruz RVO. Carbon stocks assessment of a selectively logged dipterocarp forest and wood processing mill in the Philippines. J Trop For Sci. 2006;18:212-21.

Lemenih M, Itanna F. Soil carbon stocks and turnovers in various vegetation types and arable lands along elevation gradients in Southern Ethiopia. Geoderma. 2004;123:177-88 http: //dx.doi.org/10.1016/j. geoderma. 2004. 02. 004.

Lemma B, Kleja DB, Olsson M, Nillsson I. Factors controlling soil organic carbon sequestration under exotic tree plantations. A case study using $\mathrm{CO}_{2}$ Fix model in Southwestern Ethiopia. For Model Ecol Manage. 2007;252(1-3):124-31.

Lewis SL, Lopez-Gonzalez G, Sonke B, Affum-Baffoe K, Baker TR. Increasing carbon storage in intact African tropical forests. Nature. 2009:457 https://doi.org/10.1038/ nature07771.

Mayaux P, Holmgren P, Achard F, Eva H, Stibig HJ, Branthomme A. Tropical forest covers change in the 1990s and options for future monitoring. Philos Trans R Soc B. 2007;360:373-84

Meles BW, Kelbessa E, Soromessa T. Forest carbon stocks in woody plants of Arba Minch ground water forest and its variations along environmental gradients. Sci Technol Arts Res J. 2014;3(2):141-7.

Miles L, Newton AC, De Fries RS, Ravilious C, May I, Blyth S, Kapos V, Gordon JE. A global overview of the conservation status of tropical dry forests. J Biogeogr. 2006:33:491-505.

Millennium Ecosystem Assessments. Millennium ecosystem, ecosystem and human well - being: desertification synthesis report 2002. Washington, DC: World Resources Institute; 2005. http://www.millenniumassessment.org/ documents/document.355.aspx.pdf.

Moges Y, Eshetu Z, Nune S. Ethiopian forest resources: status and future management options in view of access to carbon finances. Ethiopian climate research and networking report. Addis Ababa: UNDP; 2010.

Negassa A, Wiersum KF. Community perspectives on participatory forest management. The case of Chilimo participatory forest management scheme in Ethiopia. Ethiop J Nat Resour. 2006;8(1):57-75.

Nicholas P, Saint-André L, Henry M. Manual for building tree volume and biomass allometric equations, from field measurement to prediction. Rome, CIRAD, Montpellier: FAO; 2012. p. 215.

Pearson T, Brown S, Birdsey R. Measurement guidelines for the sequestration of forest carbon. Washington, DC: Northern Research Station, Department of Agriculture; 2007.

Pearson T, Walker S, Brown S. Source book for land use, land-use change and forestry projects; 2005.

Ponce-Hernandez R. Assessing carbon stocks and modeling win-win scenarios of carbon sequestration through land-use changes. Rome: FAO, UN; 2004.

Post WM, Izaurralde RC, Mann LK, Bliss N. Monitoring and verifying changes of organic carbon in soil. Clim Chang. 2001;51:73-99.

Pribyl DW. A critical review of the conventional SOC to SOM conversion factor. Geoderma. 2010;156:75-83.

R-Development Core Team. R: a language and environment for statistical computing. Vienna: R Foundation for Statistical Computing; 2017. ISBN 3-900051- 07- 0, URL http://www.R-project.org/.

Rhoades CC, Eckert GE, Coleman DC. Soil carbon differences among forest, agriculture and secondary vegetation in lower montane Ecuador. Ecol Appl. 2000;10:497-505

Ruiz-Peinado R, Bravo-Oviedo A, Senespleda López-Senespleda E, Montero G, Río M. Do thinning influence biomass and soil carbon stocks in Mediterranean Maritime pine wood? 2013.
Sheikh K, Bussmann RW. Altitudinal variation in soil organic carbon stock in coniferous sub tropical and broadleaf temperate forests in Garhwal Himalaya. Carbon Balance Manag. 2009;4:6 http://www.cbmjournal.com/content/4/1/6.

Shumi G. The structure and regeneration status of tree and shrub species of Chilimo forest-ecological sustainability indicators for participatory forest management (PFM) in Oromia, Ethiopia. MSc Thesis. Germany: University of Dresden; 2009.

Silver WL, Ostertag R, Lugo AE. The potential for carbon sequestration through reforestation of abandoned tropical agricultural and pasture lands. Soc Ecol Restor. 2000;8:394-407.

Sisay N. Land use, land use change and forestry (LULUCF): afforestation and reforestation. In: Clean development mechanisms investor's Guide. Addis Ababa: DNA office the Environment Protection Authority, EPA; 2010.

Solomon D, Fritsch F, Lehmann J, Tekalign M, Zech W. Soil organic matter dynamics in the sub-humid agro ecological systems of the Ethiopian highlands: evidence from $13^{\mathrm{C}}$ abundance and particle size fractionation. Soil Sci Soc Am J. 2002;66:969-78.

Soromessa T, Kelbessa E. Interplay of regeneration, structure and use of some woody species in Chilimo forest, Central Ethiopia. Sci Technol Arts Res J. 2014;3(1):90-100 https://doi.org/10.4314/star.v4i1.34.Vol (3): 1-15.

Swai G, Ndangalasi H, Munishi P, Shirima D. Carbon stocks of Hanang forest, Tanzania: an implication for climate mitigation. J Ecol Nat Environ. 2014;6(3):90-8.

Takahashi M, Ishizoka S, Ugawa S, Sakai Y, Sakai H, Ond K, Hashimoto S, Matsuura U, Marisada K. Carbon stock in litter and deadwood and soil in Japan's forest sector and its comparison with carbon stock in agricultural soils. Soil Sci Plant Nutr. 2010;56:19-30.

Temam A. Impact of disturbance on carbon stocks in HaranaBulluk natural forests, Bale Zone, SW Ethiopia. MSc Thesis. Shashemene: Wondogenet College of Forestry; 2010.

Tesfaye AM. Forest management options for carbon stock and soil rehabilitation in Chilimo dry afromontane forest, Ethiopia. PhD Thesis. Palencia: INIA- Palencia, University of Valladolid; 2015.

Tesfaye MA, Bravo F, Ruiz-Peinado R, Pando V, Bravo-Oviedo A. Impact of Changes in land use, species and elevation on soil organic carbon and total nitrogen in Ethiopian Central Highlands. Geoderma. 2016;261:70-9 0016-7061/@ 2015 Elsevier B.V. All rights reserved.

Teshome M. Progress report of natural forest research division: Addis Ababa; 2017.

Tsegaye T (2010) Bale eco-region sustainable management programme. http://www.pfmpfarmsos.org/publication.html.

Twongyirwe R, Sheil D, Majaliwa JGM, Ebanyat P, Tenywa MM, Van Heist M, Kumar L. Variability of soil organic carbon stocks under different land uses: a study in an afromontane landscape in South-Western Uganda. Geoderma. 2013:193-4 282-289. https://doi.org/10.1016/j.Geoderma.2012.09.005.

Wodajo A. Variation in carbon stock along environmental gradients in GaraMuktar Forest, West Herargae Zone, Southern Ethiopia. Dire Dawa: MSC Thesis, Haromaya University; 2018.

Woldemariam TG. Diversity of woody plants and avifauna in a dry afro-montane forest : on the central plateau of Ethiopia. Skinnskatteberg: MSc Thesis, Swedish University of Agricultural Sciences; 1998.

Yahya. Carbon stock along altitudinal gradient of araba Gugu dry afromontane forest. Switzerlands: MSC Thesis, HAFl; 2015.

Yelemfrhat T, Soromessa T, Bayable E. Forest carbon stocks in lowland area of Semien Mountains National Park: implication for climate change mitigation. Sci Technol Arts Res J. 2014;3(3):29-36.

Zanne A, Lopez-Gonzalez G, Coomes D, Ilic J, Jansen S, Lewis L, Miller B, Swenson G, Wiemann C, Chave J (2009) Global wood density database [http://hdl. handle.net/10255/dryad.235].

Zewdu E, Giesler R, H greb P. Historical land use pattern affects the chemistry of forest soils in the Ethiopian Highlands. Geoderma. 2004;118:149-65 https://doi.org/10.1016/S00016-7061(03)00190-3.

Zinn YL, Resch DS, Silva JE. Soil organic carbon as affected with Eucalyptus and Pinus in the Cerrado Region of Brazil. For Ecol Manage. 2002;166:285-94 PII: S0378-1127 (00) 00682 - X. 